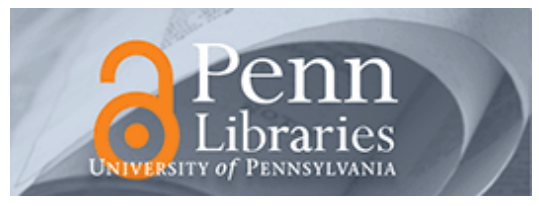

University of Pennsylvania

ScholarlyCommons

Accounting Papers

Wharton Faculty Research

$12-2007$

\title{
Performance-Based Compensation in Member-Owned Firms: An Examination of Medical Group Practices
}

Christopher D. Ittner

University of Pennsylvania

David F. Larcker

Mina Pizzini

Follow this and additional works at: https://repository.upenn.edu/accounting_papers

Part of the Accounting Commons

\section{Recommended Citation}

Ittner, C. D., Larcker, D. F., \& Pizzini, M. (2007). Performance-Based Compensation in Member-Owned Firms: An Examination of Medical Group Practices. Journal of Accounting and Economics, 44 (3), 300-327. http://dx.doi.org/10.1016/j.jacceco.2007.05.001

This paper is posted at ScholarlyCommons. https://repository.upenn.edu/accounting_papers/121

For more information, please contact repository@pobox.upenn.edu. 


\title{
Performance-Based Compensation in Member-Owned Firms: An Examination of Medical Group Practices
}

\author{
Abstract \\ We examine the importance of agency considerations for the mix of salary and performance-based \\ compensation in member-owned medical practices. Performance-based pay increases with the \\ informativeness of clinical productivity measures, and declines with greater reimbursement from \\ capitation contracts. Inexperienced physicians receive more compensation from salary, but \\ compensation mix does not change as physicians near retirement. Larger practices and practices using \\ outside management companies place more weight on performance-based compensation. However, \\ when more physicians in the group practice the same specialty, less emphasis is placed on performance- \\ based compensation. Finally, the presence of an executive partner has no influence on compensation \\ mix.
}

\section{Keywords}

compensation, pay-for-performance, agency theory, professional service firms, health care

Disciplines

Accounting 


\title{
Performance-Based Compensation in Professional Service Firms
}

\author{
Christopher D. Ittner \\ David F. Larcker \\ The Wharton School \\ University of Pennsylvania \\ Philadelphia, PA 19104-6365 \\ Mina Pizzini \\ School of Management \\ The University of Texas at Dallas \\ Richardson, TX 75083-0688
}

Draft: September 23, 2003

We would like to thank seminar participants at The University of Texas at Dallas for their comments and the Medical Group Management Association (MGMA) for granting access to their data. The financial support of the Deloitte and Touche Foundation and Ernst and Young LLP is gratefully acknowledged. 


\section{Performance-Based Compensation in Professional Service Firms}

\section{Introduction}

Agency theory provides the underlying model for most empirical studies on managerial incentives (e.g., Lambert and Larcker, 1987; Bizjak et al., 1993; Garen, 1994; Bushman et al., 1996; Aggarwal and Samwick, 1997; and others). However, considerable debate still exists regarding the extent to which observed compensation contracts reflect agency concerns. Prendergast (1999), for example, argues that empirical research supports the notion that agents respond to incentives, but has been considerably less successful in finding compelling results regarding the expected tradeoff between risk and incentives.

The purpose of this paper is to extend our understanding of theoretical agency considerations in the choice of compensation contracts. Our study examines the use of performance-based compensation in professional service firms, an industry sector that has been the subject of considerable analytical agency research. ${ }^{1}$ In particular, we focus on compensation practices for physicians in medical group practices. This setting has several distinctive features that enhance our ability to study a wide variety of agency issues. First, unlike compensation contracts in most large corporations, physician compensation contracts tend to be relatively simple combinations of fixed salary and annual cash bonus. ${ }^{2}$ This simplicity enables us to obtain reliable measures of the compensation risk imposed on employees. Second, although medical group practices operate in the same service sector (thereby controlling for confounding industry effects

\footnotetext{
${ }^{1}$ See, for example, Lee (1990), Kandel and Lazear (1992), Narayanan (1995), Ferral (1996), Gompers and Lerner (1999), and Huddart and Liang (2002), among others.
} 
that hinder cross-sectional studies spanning multiple sectors), their compensation contracts exhibit considerable variation, ranging from strictly performance-based to entirely salary-based. Third, some practices use the same compensation contract for all members, while others vary their contracts by individual physician. Fourth, the plans differ on whether performance-based compensation is based on a physician's individual performance, or on group performance with physicians receiving equal-shares of the practice's profits. Fifth, medical group practices employ a wide variety of ownership and governance structures. Practices can be owned by the physicians or by outside organizations such as health systems, hospitals, or management service organizations, can be for-profit or non-profit, and can be managed by professional management companies or by the physicians themselves. Variations in these dimensions, together with the lack of confounding industry effects, allow us to conduct powerful tests of hypotheses derived from general agency models, as well as from agency-based models investigating compensation practices in professional service firms.

We conduct our analyses using survey data collected by the Medical Group Management Association (MGMA). Our sample covers 16,659 individual physicians in 778 practices. Consistent with agency theory, we find that the extent to which individual physicians in both member- and outside-owned practices are compensated using performance-based pay increases with the informativeness of standard clinical productivity measures. However, mutual monitoring by practice members and external monitoring by outside owners or managers only serve as substitutes for performancebased compensation in member-owned firms. Physicians in member-owned firms also

\footnotetext{
${ }^{2}$ Only $13.4 \%$ of medical group practices in our study provide stock or stock option benefits to any of their physicians. Generally, these benefits are only provided when one of the physicians in the group is
} 
tend to receive less performance-based pay when a greater proportion of firm revenues are derived from capitation versus fee-for-service arrangements, consistent with efforts to reduce goal conflicts between the physician and practice. In contrast, compensation arrangements in outside-owned practices do not vary significantly on this dimension.

Although agency models generally indicate that incentive contracts should be tailored to the characteristics and preferences of individual employees, $56 \%$ of the firms in our sample use the same compensation contract for all members (i.e., the same mix of salary and performance-based bonus, or equal sharing of group profits). In both memberand outside-owned practices, the use of a common salary/bonus mix for all physicians is greater in smaller practices with little diversity in practice specialties. Member-owned firms also tend to use a common compensation mix when surgeons represent a greater proportion of members and when physicians staff hospitals, but tend to tailor the mix when there is greater variation in physician experience and in the amount of time physicians spend on non-clinical activities. However, similar tailoring is not found in outside-owned practices. The use of a common compensation mix for all physicians is not associated with contracting environment (i.e., capitation versus fee-for service) or monitoring by external owners or managers. Finally, equal-share arrangements tend to be used instead of salaries and/or bonuses in more technical practices where physicians have similar specialties and experience levels.

The remainder of the paper is organized as follows. Section 2 develops our research hypotheses. Section 3 discusses the sample and measures. Tests examining the relative weights placed on salary and performance-based bonuses are reported in Section 
4. Section 5 investigates the factors influencing the use of equal-share compensation arrangements. A summary and conclusions are provided in Section 6.

\section{Research Hypotheses}

\subsection{Background}

Physicians in medical group practices examine patients, diagnose ailments, perform medical procedures, order and interpret laboratory tests, and provide other healthcare services. As with most professional service firms, the practice is either collectively owned by the physicians (i.e., "member-owned") or owned by an external party such as a hospital, health system, or insurance company (i.e., "outside-owned"). In member-owned practices, the physician provides labor and, together with the other members of the group, acts as owner. When the practice is owned by an outside entity, the physician is an employee of that entity and typically holds no ownership interest.

Each employee in a professional service firm is an agent. The principal (or owner) can be an outside entity or the collective group of practice members. Although agency models typically assume complete separation of ownership and labor, Holmstrom (1982) demonstrates that in member-owned firms, group members can collectively act as a principal as long as the budget-balancing constraint can be relaxed. Professional service firms can, and often do, relax this constraint by running deficits or carrying over surpluses in any single year. As a result, we develop our hypotheses using standard agency theory where a risk-averse and effort-averse employee's actions cannot be

perfectly monitored by the principal. In the absence of perfect monitoring, professional service firms can induce the second best level of effort by making the agent's 
compensation contingent on contractible and observable performance measures that contain information regarding the agent's effort choice.

Nearly all performance-based bonus plans in medical group practices are based on measures of individual physician effort, such as patient encounters, relative value units (RVUs), or adjusted charges (Pontes, 1995; Hurley et al, 1996; Latham Consulting Group, 2001). Since details on the services provided by physicians are captured in standardized medical charts, it is relatively straightforward in many cases to generate standard, objective measures of physician effort that are related to the principal's objective function (Pontes, 1995; Pauly, 1996).

In contrast, patient satisfaction, quality of care, and other similar outcome measures are rarely used to compute performance-based bonuses in these groups. ${ }^{3}$ Pontes (1995) offers several explanations for why performance-based pay is seldom based on health outcomes. These include the difficulty writing contracts that consider all possible contingencies that can influence outcomes (e.g., patients' general health prior to their illness, individual differences in response to treatments, compliance with treatment recommendations, etc.); the fact that the utility of outcomes is a function of patient preferences, about which the physician may have little information; the possibility that outcome-based contracts may discourage physicians from accepting patients when the outcome is likely to be unfavorable; and the significant incentives to provide high quality care in the absence of formal outcome-based incentives (e.g., reputation effects and threats of malpractice suits, license withdrawal, and dismissal from a practice). Given the limited use of outcome measures, we develop our hypotheses assuming that performance-

\footnotetext{
${ }^{3}$ Of the practices in the MGMA database, only nine percent use quality and 11 percent use patient satisfaction measures for compensation-related decisions of any kind.
} 
based bonuses in medical group practices are tied to standard clinical productivity measures.

\subsection{Research Hypotheses}

Agency theory posits a number of factors that are expected to influence the emphasis placed on performance-based compensation. We examine three factors that have been prominently featured in this literature: the level of goal congruence between the principal and agent, the informativeness of available performance measures, and the ability to monitor agents' actions.

\subsubsection{Goal Congruence}

Agency theory emphasizes the need to align the incentives of principals with those of their agents. When the goals of the principal and agent are congruent, performance-based compensation is not required to ensure that the agent's actions are consistent with the principal's interests. However, in many cases the goals of principals and agents are not perfectly aligned, increasing the need to use compensation contracts to induce agents to operate in the principal's best interest (Prendergast, 1999).

One situation where the goals of medical group principals and agents are expected to diverge occurs when practices receive substantial revenue in the form of capitation payments (Pontes, 1995; Leone, 2002). Under capitation plans, the practice receives a fixed payment to provide care for a patient over the course of the year. The practice generates revenue when the patient designates that practice (or a physician within the practice) as his provider, regardless of whether the patient actually receives care. When a physician treats a patient on a capitation plan, the practice generates additional costs (e.g., testing, supplies, administration, etc.), but does not generate any additional revenues. 
Time spent with capitation patients also allows less time for fee-for-service patients.

Consequently, practices with substantial capitation reimbursement are likely to desire fewer encounters and procedures per patient in order to maximize financial performance. ${ }^{4}$

Physicians paid on a productivity or fee-for-service basis, on the other hand, have incentives to overprovide services to increase their compensation, even when the additional services do not provide higher-quality care to the patient (Leone, 2002). To minimize this conflict, Pontes (1995), Kennedy and Buckley (1997), and Leone (2002) argue that performance-based pay should receive less emphasis when revenues from capitation plans are greater in order to offset physicians' incentive to overprovide services. Thus, our first hypothesis:

Hypothesis 1: The extent of performance-based pay is negatively associated with the percentage of group revenue received from capitation plans.

\subsubsection{Performance Measure Informativeness}

Agency theory suggests that the intensity of performance-based compensation also depends upon the informativeness of available performance measures, as reflected in their signal-to-noise ratio (e.g., Holmstrom, 1979; Banker and Datar, 1989; and Lambert and Larcker, 1987). Holmstrom and Milgrom (1991), for example, show that in situations where it is difficult to measure critical performance dimensions, aggressively rewarding measured performance yields dysfunctional outcomes as agents allocate their efforts to maximize compensation. Moreover, simply adding measures does not ensure optimal allocation of effort because it creates incentives for employees to attend

\footnotetext{
${ }^{4} \mathrm{We}$ assume that the goal of medical practices, which are predominantly for-profit entities, is to maximize practice profits, subject to quality constraints. We also assume that malpractice suits, reputation concerns, and insurer scrutiny of bills effectively limit the extent to which physicians can reduce quality. Financial viability is also important in practices owned by not-for-profit organizations (Prince, 1998), though potentially not the most important factor (Newhouse, 1970). We control for non-profit status in our tests to account for potential differences in objective functions.
} 
selectively to those dimensions that are easily measured or controlled. Uninformative or noisy measures also increase an agent's compensation risk by increasing the likelihood that an agent's effort will go unrewarded. Consequently, reliance on performance-based compensation should be negatively related to the extent to which the agent's job contains dimensions or tasks that are difficult to evaluate.

These results imply that medical group practices will use performance-base compensation to a lesser extent when standard clinical productivity measures are less informative. Yet, despite the strong theoretical support for this prediction, Prendergast's (1999) review concludes that empirical studies examining the relation between compensation contract design and proxies for performance measure informativeness have produced only mixed results. We therefore test the following hypothesis:

Hypothesis 2: The extent of performance-based pay is positively related to the informativess of clinical productivity measurse.

\subsubsection{Monitoring Ability}

Compensation contracts are not the only means to motivate agents. Direct monitoring by the principal or fellow employees provides an alternative to imposing risk through costly contingent compensation contracts. When principals can directly observe whether agents are taking desired actions, and can reward or punish agents based on these observations, incentive compensation is not necessary to drive the agents' behavior. For example, agency models by Lee (1990), Kandel and Lazear (1992), Chee and Yoo (2001), Huddart and Liang (2002), and others examine the relation between compensation and monitoring by partners or team members, and show that internal monitoring by peers can substitute for performance-based pay in some circumstances. 
Other studies have examined how monitoring by external principals, such as boards of directors or large shareholders, influences compensation plan design. The majority of these studies examine the effects of ownership concentration and structure on compensation plans in large, public companies. Results have been mixed, leading Pavlick et al. (1993) and Shleifer and Vishny (1997) to conclude that ownership concentration does not vary enough in these companies to significantly impact compensation design, or that it has no influence on compensation design. Mixed results have also been found in studies of small and privately-held firms. Ke et al. (1999) find no association between executive compensation and accounting performance in privately held insurance companies, which they attribute to stronger monitoring in these firms relative to public insurance companies. In contrast, Cavalluzzo and Sankaraguruswamy (2003) find a positive association between pay and accounting performance in small, frequently private, firms, with a stronger association when the number of shareholder increases.

Studies in the health care sector, on the other hand, generally support the tradeoff between monitoring and incentive compensation. Lambert and Larcker (1995) find that more active hospital boards of directors appear to monitor and direct hospital administrators more closely, rather than using performance-based compensation arrangements. Lee (1990) finds that medical group practices with a greater share of capitated health management organization (HMO) patients place less weight on productivity-based compensation but have more extensive systems for monitoring physicians. Leone (2002) hypothesizes that it is more costly for national HMOs to monitor physicians than for locally-owned HMOs due to the distance between 
management and physician, leading to greater use of capitation compensation plans and less use of fee-for-service incentives in the national organizations. He finds support this hypothesis in for-profit national HMOS, but not in non-profits.

The discussions of monitoring-compensation tradeoffs in the agency literature lead to the following hypotheses:

Hypothesis 3: Performance-based pay is inversely related to the ability of practice member and/sor other parties to directly monitor the physician.

\subsubsection{Use of Common Compensation Plans}

Although agency theory typically focuses on the design of compensation plans for individual agents, many firms use common compensation plans for entire groups of workers. The common plans can use the same mix of salary and bonus for groups of employees, but tie the bonus payout to individual performance measures, or link performance-based compensation to group results through team-based incentives or profit sharing. Analytical models provide a number of potential explanations for the use of common compensation plans. If the principal seeks to attract and motivate agents with similar backgrounds, skills, and risk preferences, it may be optimal to compensate all workers using the same mix of salary and bonus (Gaynor and Gertler, 1995).

Alternatively, as diversity in tasks and employee characteristics increases, monitoring becomes more difficult and performance measure informativeness begins to differ among employees, making common compensation plans for all agents less useful.

The use of common or group-based incentives is also likely to vary with the ability of agents to cooperate and monitor each other. For example, Holmstrom and 
Milgrom (1990) and Itoh (1993) demonstrate that in cases where it is Pareto-efficient for agents to coordinate their efforts and share risks, it is optimal for principals to use simple group incentive plans to encourage this activity. Che and Yoo (2001), in turn, show that in situations where cooperation between team members is desired, team-based incentives provide members with the motivation and means to exert peer sanctions, which lowers the cost of incentives. Similarly, Kandel and Lazear (1992) demonstrate that equal sharing of profits among partners creates incentives for peer pressure and mutual monitoring. Moreover, their model indicates that the resulting peer pressure and monitoring are more effective when workers are more homogeneous and perform similar tasks, and when profits are shared by a small group. Thus, our fifth hypothesis:

Hypothesis 4: The use of common compensation plans (i.e., the same mix of salary and bonus or the use of equal share arrangements) is negatively associated with the degree of intra-firm variation in monitoring ability and performance measure informativeness.

\section{Research Design}

\subsection{Sample}

Our data come from a nationwide survey developed and conducted by the Medical Group Management Association (MGMA). Surveys were mailed to 5,193 MGMA member practices in February of 1999 asking about their 1998 operations. Responses were received from 1,772 practices. The MGMA staff eliminated 114 surveys due to incomplete data reporting or duplication and 49 surveys due to late submission, yielding an adjusted response rate of $30.98 \%$.

The mean (median) practice in our sample has $20(9)$ members. We retain observations from physician-owned practices with five or more members. This restriction is imposed because a minimum of 2 members is necessary for moral hazard to 
be present and 3 members to prevent shirking from being directly traceable. ${ }^{5}$ We also retain all observations from practices owned by hospitals, health systems, insurers, foundations, and other external organizations because the physician is an employee (or agent) of a larger organization. Our final sample consists of 897 medical group practices and 17,332 individual physicians.

\subsection{Variables}

\subsubsection{Performance-based compensation}

The extent of performance-based compensation is measured using a survey question asking respondents to indicate, for each physician in the practice, the method used to determine compensation, from the following list: 100\% individual productivity ( $0 \%$ salary), $50-99 \%$ individual productivity (1-50\% salary), $50-99 \%$ salary ( $1-50 \%$ productivity), $100 \%$ salary ( $0 \%$ productivity), or $100 \%$ equal share. ${ }^{6}$ Examples of productivity measures given in the survey instructions include gross charges, encounters, and relative value units (RVUs). Consistent with evidence in the practitioner literature (Hurley et al, 1996; Latham Consulting Group, 2001), this question assumes that individual performance-based compensation is a function of clinical productivity. The amount of compensation not based on productivity or equal shares is defined as "fixed" or "guaranteed salary."

\footnotetext{
${ }^{5}$ Our results change little when the analyses are run with minimum practice sizes of three, ten, and 15 physicians.

${ }^{6}$ The survey also allowed an "other" response to this question. Of the 24,541 physicians in the MGMA data base, only $217(0.88 \%)$ gave this response. These responses are eliminated from our analyses. We conducted a number of tests to establish the construct validity of our categorical compensation variable. As reported in Appendix A, the statistical relations between compensation and productivity are consistent with the categorical responses on pay-performance sensitivities. In addition, mean total compensation levels for each of the survey categories confirmed that the amount of pay is increasing in the amount of risk imposed on a physician.
} 
In practices using some combination of salary and individual performance-based pay, we measure pay-performance intensity for each physician using the midpoint in each response category: 0 if compensation is entirely salary-based; 25 if $1-50 \%$ of compensation is based on performance; 75 if 50\%-99\% of compensation is based on productivity; and 100 if compensation is entirely productivity-based. ${ }^{7}$

In tests comparing the use of salary and/or bonus to the use of equal shares, the variable Equal Shares is coded one if equal sharing of profits is used to compensate a physician, and zero if some combination of salary and bonus is used.

\subsubsection{Goal congruence}

We test our first hypothesis using the percentage of group revenues derived from capitation plans (denoted Capitation). We expect less weight on performance-based pay when more revenue is received from capitation contracts, thereby reducing goal conflicts between the physician and practice. Capitation levels range from $0 \%$ to $100 \%$ of revenues $($ mean $=6.8 \%)$.

\subsubsection{Informativeness}

We use four variables to proxy for the informativeness of standard clinical productivity measures.

Hospital staffing. Physicians in some groups are employed by or contract with a hospital to staff a department. Physicians who staff hospital departments often have relatively little control over their workflow, which is driven by overall patient volume at the hospital. For example, the number of cases processed by hospital-based physicians depends primarily on hospital volume, which is influenced by the hospital's reputation

\footnotetext{
${ }^{7}$ Since the performance-based compensation variable is based on categorical responses, we repeated
} 
and various uncontrollable events (e.g., weather conditions). Consequently, clinical productivity measures may provide little information on the physician's effort level, and may impose too much compensation risk on the physician. We therefore predict that pay-performance intensity is lower for physicians in group practices that staff hospitals. The variable Staff equals one if the group staffs a hospital department, and zero otherwise.

Physician experience. Pauly and Gaynor (1990) find that a physician's clinical efficiency improves with experience. The initial years after residency may constitute additional training for a physician where effort does not directly translate into clinical performance. Young physicians may also expend effort in building a patient base and reputation building that is not reflected in clinical-based performance measures. Thus, the health economics literature suggests that the use of performance-based compensation should increase with physician experience because clinical performance measures are more informative about physician effort.

This result is similar to economics literature on partnerships (Akerlof and Katz, 1989; Lazear, 1991; Landers et al, 1996; Gompers and Lerner, 1999). If the principal and agent have the same initial information, less experienced professionals are expected to work harder in the absence of explicit performance-based contracts in order to convince the principal that they have high potential. Furthermore, less experienced workers may be more willing to supply effort without performance-based compensation because doing so increases the likelihood that the worker will survive in the firm long enough to attain the high compensation that is earned by experienced employees. 
An alternative perspective is that the principal does not know the ability of the agent and uses performance-based compensation contracts to induce effort and/or to attract more capable agents. Gibbons and Murphy (1992), Milbourn (1998), and others develop this theory and find that as the firm gains more experience with the agent, there is less uncertainty about the agent's ability and less need to impose costly risk on the agent. Thus, once the principal learns the agent's "type," an appropriate fixed salary is paid to the agent and no compensation risk is imposed. Ignoring incentive issues that may arise as the agent approaches retirement, this economic theory suggests that there is an inverse relation between the use of performance-based compensation and physician experience.

Although physician experience is an important factor in the contracting environment, it has a theoretically ambiguous relation with the use of performance-based compensation contracts. Since the impact of physician experience is unlikely to be a linear function of years in the physician's chosen specialty, we use two indicator variables to measures the number of years the physician has practiced in his or her specialty: $<=2$ years, which equals one if the physician has two or fewer years experience in the specialty, and zero otherwise; and 3-5 years, which equals one if the physician has three to five experience in the specialty, and zero otherwise.

Non-Clinical Activity. Although medical group practices use productivity measures almost exclusively when determining performance-based compensation, physicians can have many responsibilities in addition to their clinical duties (e.g., resident training, research, and administration). Traditional clinical measures provide little or no information regarding non-clinical responsibility, and can induce dysfunctional behavior 
(Holmstrom and Milgrom, 1991). Moreover, Holmstrom and Milgrom (1991) point out that it is extremely difficult to measure tasks such as education and research, and argue that in multi-tasking environments where effort is difficult to measure on some dimensions, performance-based pay can be counter-productive. We therefore expect the extent of a physician's non-clinical responsibility to be inversely related to the use of performance-based contracts. The variable Non-Clinical equals the percentage of fulltime-equivalent (FTE) units that a physician devotes to non-clinical work.

\subsubsection{Monitoring Ability}

Group Size. One factor that is likely to impact the ability to monitor the physician is the size of the group practice. As the size of the practice increases, it becomes increasingly difficult for physicians to mutually monitor each other or for external owners or managers to assess agents' actions (Holmstrom, 1982; Kandel and Lazear, 1992). ${ }^{8}$

Our first proxy variable for monitoring is the natural logarithm of the number of full-time physicians in the group practice (denoted Size). We expect larger practices to place more weight on performance-based compensation.

Physician Specialty. Another factor affecting the ability to monitor practice members is the complexity of services performed by the physician. Highly specialized physicians (e.g., neurosurgeons) often treat non-routine ailments that may not have an established medical protocol or benchmark performance. In contrast, there are wellestablished standards for the number of patients a primary physician can examine (Pontes, 1995). Thus, the ability to monitor a physician (either by other physicians or

\footnotetext{
${ }^{8}$ Kandel and Lazear (1993) argue that incentives do not always weaken as firm size increases. For example, agent effort might increase with the number of employees because of increased peer pressure also increases with size and this mitigates the free rider problem. However, they also argue that the benefits from more monitors are likely to decline as the firm gets extremely large.
} 
other parties) declines as a physician provides a more complex service to patients. Our second set of monitoring proxies therefore relates to the physician's specialty grouping. The three groupings include Primary care (family practice, general internal medicine, or general pediatrics), Surgical (all surgical specialties plus the specialties of gynecology, obstetrics, opthalmology, otorhinolaryngology, or urology), and Non-surgical (anesthesiology, emergency medicine, hematology/onocology, nuclear medicine, oncology, pathology, radiology, or other specialties not included in the primary care or surgical categories). Each variable is coded one if the physician's specialty fits into that grouping, and zero otherwise. Based on their level of complexity, we expect surgical practices to use more performance-based compensation than non-surgical practices, and non-surgical practices to use more performance-based compensation than primary care practices. ${ }^{9}$

Similarity in Specialties. Although the type of specialty is critical for monitoring, physicians in member-owned practices can have very similar skills and this will increase their ability to monitor each other (Kandel and Lazear, 1992). For example, it may be very difficult to monitor a neurosurgeon, but this activity is clearly easier for other neurosurgeons than for a primary care physician. Our fourth proxy for monitoring ability is therefore the concentration of specialties in the practice. The variable Specialty diversity represents the number of different specialties in the group scaled by the number of group members (with smaller values indicating greater diversity). We expect greater diversity to increase the weight on performance-based compensation.

Use of Professional Management Companies. Professional service firms sometimes engage the services of an outside management company to help manage the

\footnotetext{
${ }^{9}$ The Primary care grouping is omitted from the analyses to permit model estimation.
} 
practice or perform administrative functions, such as invoicing and scheduling. These firms are known as management services organizations (MSO) or physician practice management corporations (PPMC). In many cases, outside management companies provide services that allow practices to more closely monitor individual physicians (Dynan et al., 1998). Accordingly, these services should improve monitoring and substitute for the use of performance-based compensation contracts. We measure the use of outside management firms using an indicator variable that has a value of one if the practice uses an MSO or PPMC and zero otherwise (denoted Management co.).

Physician executive. Rather than using an outside management service, memberowned practices can appoint one of the group members to manage the practice and grant him an equity interest. The executive partner essentially fulfills the role of the principal because he does not contribute directly to the group's productivity, but the value of his ownership interest depends upon the productivity of the other physicians in the group. However, the monitoring by this executive partner can substitute for the use of a performance-based compensation contract. This is consistent with Alchain and Demsetz (1972), who argue that inefficiency in partnerships will prompt partnerships to hire a principal to monitor agents and grant the monitor an equity interest. Similarly, Huddart and Liang (2002) claim that when monitoring is personally costly to a partner who undertakes the monitoring, each individual partner shirks the monitoring task. Their model indicates that it becomes optimal for partnerships to appoint one partner to specialize in monitoring. Accordingly, productivity-based compensation is predicted to be lower for those member-owned practices that have an executive partner. The variable 
Physician executive equals one if a member-owned practice uses a physician executive partner to run the practice and zero otherwise.

Outside Ownership. Some practices are owned by outside entities such as hospitals, health systems, and foundations, as opposed to being member-owned practices. These outside entities are in the business of administering the provision of health care and have elaborate control systems that gather information on physician decisions. The monitoring by these outside entities should substitute for the use of a performance-based compensation contract (Lee, 1990). We measure outside monitoring using indicator variables that have a value of one if the practice is owned by an MSO or PPMC (denoted MSO/PPMC owns) or some other organization such as a foundation (denoted Other owner). Hospital owned practices serve as the base case in the models.

\subsubsection{Controls}

Not-for-profit. Prior studies find less use of fee-for-service or productivity-based pay in non-profit medical groups (Lee, 1990; Leone, 2002). We include an indicator variable for practices owned by non-profit entities (denoted Not for profit) to control for this possibility.

Labor markets. Compensation methods in medical practices are likely influenced by labor market factors, such as the degree of competition, the extent of HMO penetration, and the demand for physician services (Hurley et al., 1996; Leone, 2002). Two sets of categorical variables are used to control for labor market influences. The first set controls for urban, suburban, and rural settings. The second set controls for region (Northeast, North Atlantic, Mid-Atlantic, Rocky Mountain, Northwest, Southwest, 
Eastern Midwest, Lower Midwest, Upper Midwest, Southern California, and Northern California). Urban and Upper Midwest indicator variables are excluded from the models.

\subsection{Descriptive Statistics}

Descriptive statistics are reported in Table 1. Panels A and B provide information on pay practices and professional characteristics for the individual physicians in our sample. Significant differences exist between member- and outside-owned groups. Whereas $61 \%$ of physicians in member-owned groups receive at least half of their compensation in the form of productivity-based bonuses, only $40 \%$ of physicians in outside-owned groups have more than $50 \%$ of compensation tied to bonuses. Similarly, $27 \%$ of physicians in outside-owned groups have no performance-based pay versus $14 \%$ in member-owned groups. Equal shares are used to compensate $6 \%$ of physicians in member-owned groups, but only seven physicians $(0.0002 \%)$ in outside-owned groups.

Physicians in member-owned groups tend to receive higher total compensation $($ mean $=\$ 258,409$ vs. $\$ 178,983$; median $=\$ 210,000$ vs. $\$ 152,209)$, consistent with the greatest use of performance-based pay in these practices. On average, physicians in member-owned practices are less likely to work in primary care specialties $(29.9 \%$ vs. $59.8 \%)$, have fewer colleagues in the group practicing the same specialty $(1.86$ physicians vs. 2.42), have more experience (13.8 years vs. 12.8 years), and spend less time on non-clinical activities ( $4.4 \%$ of time vs. $6.6 \%)$.

Panels C and D examine variations in group-level pay practices and characteristics. In both member- and outside-owned groups, the majority of group members are covered by a common compensation plan. Overall, $51.4 \%$ of groups pay all 
physicians using the same salary/bonus mix, and $71.0 \%$ use the same mix for at least $80 \%$ of their physicians. Equal shares are used in 121 groups (13.5\%), only two of which are outside-owned. Nearly $5 \%$ of the groups use equal shares for all physicians, and $7.8 \%$ use equal shares for $80 \%$ or more of their physicians.

Member-owned groups tend to have fewer physicians (mean $=9$ physicians vs. $15)$, less diversity in the number of specialties in the practice (mean $=0.26$ vs. 0.29 ), a larger percentage of surgical and non-surgical specialists (mean $=40.7 \%$ and $37.1 \%$, respectively, vs. $12.1 \%$ and $17.4 \%)$, less variation in experience (mean $=0.77$ vs. 0.84 ), fewer physicians with less than five years experience (mean $=7.7 \%$ with two or fewer years experience and $12.4 \%$ with three to five years vs. $13.3 \%$ and $18.8 \%$, respectively), and less variation in the amount of time spent on non-clinical activities (mean $=8 \%$ vs. $11 \%)$.

Outside-owned practices are more likely to staff hospitals (25.9\% for outsideowned vs. $20.1 \%$ for member-owned) and receive more reimbursement from capitation contracts (mean $=11.8 \%$ of revenues vs. $5.6 \%$ ). However, the use of management companies for providing administrative services is not statistically different in the two groups. Physician executives are used by $12 \%$ of the member-owned practices, all of which are for-profit entities. Nearly three-quarters (73.6\%) of outside-owned practices are owned by hospitals, $3.4 \%$ by MSOs or PPMCs, and $23.0 \%$ by other owners (e.g., universities, insurance companies, etc.), and $67.2 \%$ are non-profit.

\subsection{Correlations}


Table 2 provides correlations among the variables used in our physician-level tests. In general, the correlations are quite small, suggesting no problems with multicollinearity. Only three substantive correlations exceed 0.30 in absolute value. Groups with more members are more likely to staff hospitals, receive more revenues in the form of capitation payments. Physicians in larger groups also tend to work with more physicians in the same specialty.

\section{Factors Influencing the Weights on Salary and Performance-Based Pay}

\subsection{Physician-Level Tests}

Our first set of tests examine the use of performance-based incentive plans that base compensation on individual (rather than group) performance. We begin by examining pay practices for individual physician. Since observations from physicians in the same group may not be independent, Huber/White robust standard errors are used to assess the significance of coefficients (Huber, 1967; White, 1980). The robust standard errors enable us to relax the assumption of independence within practices. Table 3 contains ordinary least squares regression estimates for member-owned and outsideowned firms. The model is highly significant $(\mathrm{p}<0.01)$ for both samples, with adjusted r-squareds of 30 percent and 46 percent for the member-owned and outside-owned samples, respectively. Moreover, the results identify both similarities and differences between member-owned and outside-owned practices.

Consistent with Hypothesis 1, our measure of goal incongruence, the size of a physician's capitated patient base, is negatively and significantly ( $p<0.01$, two-tailed) associated with the use of performance-based pay in member-owned practices. This suggests that a relatively high capitation base conflicts with the incentives created by 
performance-based compensation plans in member-owned firms. However, capitation levels do not explain compensation practices in outside-owned practices.

Results for both member-owned and outside-owned firms are consistent with our hypothesis that performance-based pay receives less weight in settings where clinical productivity measures are less informative. All four measures of reduced information content (Staff hospital, <=2 years, 3-5 years, Non-clinical) are negatively and significantly ( $\mathrm{p}<0.01$, two-tailed) associated with the use of performance-based pay in member-owned firms. Coefficients on three of the four proxies for reduced information content $(<=2$ years, 3-5 years, Non-clinical $)$ are also negative and significant $(\mathrm{p}<0.05$, two-tailed) in the outside-owned sample.

Our proxies for monitoring ability exhibit much stronger associations with payperformance intensity in member-owned practices than in outside-owned. As predicted, physicians who have more practice colleagues with the same specialty receive less weight on performance-based compensation. This relation is significant at the $5 \%$ level in member-owned practice, and only marginally insignificant $(p<0.15$, two-tailed) in outside-owned practices. This evidence suggests that when a larger number of group members practice the same specialty, mutual monitoring is more effective, allowing the practice to impose less compensation risk on the physician. Size is positive and significant in member-owned practices, consistent with larger groups making greater use of performance-based pay to account for the greater difficulty in monitoring. The coefficient on Size is also positive in the outside-owned sample, but is statistically insignificant. 
Contrary to our predictions, member-owned practices use significantly less $(\mathrm{p}<$ 0.01, two-tailed) performance-based pay for physicians in non-surgical specialties relative to those in primary care specialties, and do not impose greater pay-performance intensity on surgeons. In addition, specialty group has not significant relation with compensation practices in outside-owned groups.

We also find no support for the prediction that external monitoring capability, as measured by Management co. in both samples, Physician executive in member-owned practices, and type of owner in outside-owned practices, is negatively associated with performance-based pay. In fact, contrary to our predictions, performance-based pay is greater ( $\mathrm{p}<0.01$, two-tailed) in member-owned practices that use outside management companies than those that do not. This may suggest that management companies improve the informativeness of performance-based measures by increasing the reliability, timeliness and/or accuracy of performance data. Management companies may also enable physicians to devote more time to enhancing their clinical skills and building the practice, which eventually translates into greater clinical productivity.

Although we made no predictions regarding the impact of ownership on compensation design in outside-owned firms, "other" outside ownership is both negatively and significantly ( $p<0.01$, two-tailed, respectively) associated with performance-based pay, relative to hospital-owned practices. Foundations constitute the majority of "other" outside-owned entities. Foundations are formed with the goals of performing research in a specific field or caring for a defined population or disease. Progress towards such goals is not easily assessed with common productivity-oriented clinical measures, potentially explaining the negative relation. 


\subsection{Intra-firm variation in salary/bonus mix}

In the second set of tests, we regress both a dichotomous and a continuous measure of intra-firm variation in compensation methodology on proxies for variation in internal monitoring capability and informativeness, and a set of control variables. The unit of analysis in these tests is the practice. We include all firms in which the predominant method of compensation is some combination of salary and/or bonus based upon individual performance. ${ }^{10}$

The dichotomous measure of intra-firm variation in compensation (denoted Same salary/bonus mix) takes the value of 1 if every member in the group receives the same combination of salary and bonus (for e.g., all members receive $40 \%$ salary and $60 \%$ bonus), and 0 otherwise. Results of the logistic regression using same salary/bonus mix are contained in Model 1 of Table 4. The chi-squared statistic is significant at the 1 percent level or better in both samples, and the Negelkerke r-squareds are $22.7 \%$ and $31.8 \%$ for the member-owned and outside-owned sample, respectively. Consistent with our hypotheses, the results suggest that the larger the group and the more diverse the training, tasks, experience levels, and responsibilities of its members, the more likely that the firm will vary the salary/bonus mix. The probability that a member-owned firm uses the same compensation method with all members is negatively associated ( $\mathrm{p}<0.01$, twosided) with firm size, negatively associated ( $\mathrm{p}<0.01$, two-sided) with the relative number of different specialties practiced (Specialty diversity), positively associated $(\mathrm{p}<0.10$, two-sided) with the homogeneity of the specialties practiced (\% Non-surgical and $\%$ 
Surgical), and positively associated ( $\mathrm{p}<0.10$, two-sided) with the use of team-based production (Staff hospital). Further, the probability that a member-owned firm uses a single compensation method is negatively associated ( $p<0.05$, two-sided) with the degree to which group members vary in experience (Variation in experience) and nonclinical responsibility (Non-clinical variation). The results for Size and Specialty diversity also hold in the outside-owned partition. Interestingly, in outside-owned firms, heterogeneity in the classification of specialties practiced (i.e., primary care, nonsurgical, surgical), variation in experience levels, and variation in non-clinical responsibilities do not appear to provide a significant impetus for outside-owned firms to vary the salary/bonus mix.

The last two columns of Table 4 (Model 2) contain OLS regression results for the continuous measure of intra-firm variation in compensation, \% Physicians with same salary/bonus mix. The model is significant $(\mathrm{p}<0.01)$ in both samples; but, it has greater explanatory power with member-owned firms (adjusted r-squared $=13 \%$ ) than outsideowned firms (adjusted $r$-squared $=7 \%$ ). The results support our hypotheses and reinforce the findings from the logit model. Consistent with the logit model, the proportion of physicians that are compensated in the same manner is negatively and significantly $(\mathrm{p}<$ 0.01, two-tailed) associated with size in outside-owned firms and Specialty diversity in all firms. ${ }^{11}$ As in the logit model, the coefficient on S.taff hospital is positive and significant ( $\mathrm{p}<0.10$, two-tailed) in the member-owned sample. In contrast to the logit model, the

\footnotetext{
${ }^{10}$ The predominant method of compensation is the method used with the greatest number of members in a group. The predominant method of compensation is used with at least $50 \%$ of a group's members in all but one of the 776 firms in our sample.

${ }^{11}$ We also substituted categorical size variables for the continuous measure of size. Intra-firm variation in salary/bonus mix is significantly ( $\mathrm{p}<0.01$, two-tailed) lower in firms with 5-7 members when compared with those that have more than 7 members. In the outside-owned partition, intra-firm variation in salary/bonus mix is also significantly ( $\mathrm{p}<0.01$, two-tailed) lower in firms with $8-10$ members.
} 
overall variation in experience levels is not significantly associated with variation in pay practices in either partition. However, the coefficient on $\%<=2$ years is negative and significant $(\mathrm{p}<0.01)$ in both partitions, which suggests that the salary/bonus mix used with new physicians differs from that used with more experienced physicians. Finally, consistent with the logit results, the greater the variation in non-clinical activities in member-owned firms, the smaller the proportion of physicians that are compensated using the same salary/bonus mix $(\mathrm{p}<0.01$, two-sided $)$.

\section{Factors Influencing the Use of Equal Shares}

In our final set of tests, we use a logistic regression model to compare firms that compensate members on an equal shares basis (i.e., based upon the group performance) to those that compensate members with some combination of salary and/or bonus (i.e., based upon individual performance, responsibilities, etc.). As in the previous set of tests, the practice is the unit of analysis. Since only two of the outside-owned practices use equal shares, we limit our anlaysis to member-owned practices.

A single firm may use equal shares with some members and a salary/bonus combination with other members. T therefore, we use three different specifications to test the hypothesis. In the first specification (Model 1), we compare firms that predominantly use equal shares to compensate their physicians (119 firms) to those that predominantly use any combination of salary and/or bonus (604 firms). In the second specification (Model 2), we compare firms that use equal shares with all members (42 firms) to those that use the same combination of salary and/or bonus with all members (349 firms). 
Results are presented in Table 5. Both models are significant at the one percent level, with Negelkerke r-squares of approximately $26 \%$. Consistent with our predictions, the results suggest that firms are significantly more likely to use equal shares when group members generally practice in the same or related specialties and have similar levels of experience. The probability that a firm uses equal shares is significantly decreasing in the relative number of different specialties practiced (both models, $p<0.01$, two-tailed) and increasing in the percentage of members that practice in related specialties (model 1 $\mathrm{p}<0.01$, model $2-\mathrm{p}<0.05$, two-tailed). Firms whose members vary widely in experience are less likely to use equal shares (both models, $\mathrm{p}<0.01$, two-tailed). Finally, the firms in the first specification (model 1) that have a high percentage of new members ( 2 or fewer years of experience) are also significantly ( $p<0.10$, two-tailed) less likely to use equal shares.

The third specification (model 3) compares firms that use equal shares with all members to firms that use $100 \%$ bonus with all members. Compensation is entirely performance-based for all the firms in this specification. With equal shares, group performance determines each member's compensation, and with $100 \%$ bonus-based pay, individual performance determines each member's compensation. Consistent with our prediction, the greater the variation in experience, the less likely that the firm will use equal shares ( $\mathrm{p}<0.05$, two-tailed). However, contrary to our prediction, practices that staff hospital departments are less likely to use equal shares $(\mathrm{p}<0.10$, two-tailed).

\section{Conclusion}

This paper examines the determinants of compensation in professional service firms and provides evidence that such firms support basic agency predictions regarding 
the information content of performance measures and monitoring accuracy. Tests of informativeness indicate that the proportion of risk-based pay is lower for those with less non-clinical responsibility, presumably because standard performance measures provide relatively little information regarding effort devoted to non-clinical tasks. Firms use performance-based pay more extensively with physicians that have greater experience; however, there are both informativeness-related and reputation-related explanations for this result. Also consistent with informativeness predictions, the proportion of performance-based pay is significantly smaller for member-owned practices that staff hospital departments and serve a relatively large proportion of capitated patients. This potentially indicates that such physicians have little control over the flow over their work, and that standard clinical performance measures do little to indicated whether the physician's actions were in accordance with the organization's objectives when patients are covered under capitation plans.

Tests of the impact of firm complexity on the use risk-based pay also support standard agency predictions regarding the risk-monitoring trade-off. We find that payperformance sensitivity increases significantly with practice diversity, size, and the degree of physician specialization, all of which reduce monitoring accuracy. The impact of diversity on pay-performance sensitivity is significantly larger in physician-owned practices compared with non-physician-owned practices, while the impact of size on payperformance sensitivity is smaller. Consistent with predictions regarding monitoring proficiency, physician-owned practices that appoint one of the co-owners to oversee the practice use significantly less performance-based pay. Contrary to predictions, there is 
no evidence that management companies improve monitoring proficiency within medical practices.

In general, member-owned firms show more support for agency predictions than those owned by outside entities, perhaps indicating that member-owned practices potentially conform better to the simple agency model on which the hypotheses are based. This seems reasonable, as non-physician-owned practices are owned by large hospital, health system, foundations, and other organizations in which a board, or less frequently, stockholders, constitute the "principal". Simple agency models, which do not directly address such multi-tiered organizations, may be better-suited for the flat organizational structure of the typical labor-managed physician-firm. Furthermore, in member-owed firms, the wealth of those actually negotiating contracts, i.e. the member themselves, directly depends upon compensation contract design. Thus, they have a significant incentive to choose an efficient contract. Conversely, in outside-owned practices, the administrative employees who negotiate physician contracts on behalf of the principal often have little or no explicit monetary interest in the performance of the physician practice.

Finally, tests of intra-firm variation in pay-performance intensity indicate that the larger the firm and the more it varies in non-clinical responsibility and medical specialization, the more likely that it will vary its compensation methodology. Furthermore, physicians practices that staff hospital departments are less likely to vary compensation because tasks performed by individual members do no vary significantly. These results further confirm agency predictions in that they demonstrate that variation in 
compensation is attributable to factors that impact informativeness and monitoring accuracy. 


\section{Appendix A}

\section{Validity Tests for Performance-Based Compensation Variable}

Our performance-based compensation variable is based on categorical responses regarding the proportion of a physician's compensation based upon clinical productivity measures. In this Appendix, we conduct analyses to validate the survey responses. Specifically, we estimate pay-for-performance sensitivities using physician-level compensation and productivity data. For each practice with at least ten members $(\mathrm{n}=$ 450 different practices), compensation was regressed on a measure of clinical performance (denoted PERFORM), along with measures of a physician's training, experience, and non-clinical responsibility:

\section{(A-1) $\quad$ INCOME $_{\mathrm{i}}=\alpha_{\mathrm{i}}+\beta_{1, \mathrm{i}} \mathrm{PERFORM}+\beta_{2, \mathrm{i}}$ TRAINING + $\beta_{3, \mathrm{i}}$ EXPERIENCE $+\beta_{4, \mathrm{i}} \mathrm{NON}-\mathrm{CLINICAL}+\varepsilon_{\mathrm{i}, \mathrm{j}}$,}

where PERFORM is a measure of clinical performance (gross charges or RVUs), TRAINING is the number of years beyond medical school required for the specialty the physician practices, EXPERIENCE is the number of years a physician has practiced in his/her specialty area, and NON-CLINICAL is the proportion of a physician's time devoted to non-clinical work.

\section{A.1 Clinical Performance Measures}

Physician practices primarily based performance upon the amount of charges generated by a physician, RVUs, or patient encounters, although some practices indicated they used two or more of these measures to evaluate performance (Table A-1). ${ }^{12}$ Out of

\footnotetext{
${ }^{12}$ Professional gross charges is only an approximation of the actual charge-based measure used. Groups reported using one of the following charge-based measures: gross charges, adjusted charges, and medical revenues. Gross charges are the full value, at the practices undiscounted rates, of all service provided.
} 
450 practices, 242 practices (54\%) based performance on charges only, $37(8 \%)$ used RVUs only and 11 (2\%) used patient encounters only. Ninety-seven practices (22\%) used some combination of these measures, while 63 practices (14\%) did not use any of these standard clinical performance measures to compensation physicians.

For the 63 practices that did not use clinical performance measures to evaluate physician performance, 27 (43 percent) reported that they did not compensate physicians based upon clinical performance (i.e., physician worked on a 100\% salary basis), while 35 percent reported that they based less than half of compensation on clinical performance. Thus, responses of those practices not using a standard clinical performance measures are consistent with the compensation methodology reported by these practices.

\section{A.2 Estimation of proportion of pay based upon performance}

Equation (A-1) was estimated for each of the 334 groups that used a charge-based measure. ${ }^{13}$ Two-hundred and eighty (280) of the 334 groups had sufficient data to calculate a coefficient for professional charges, $\beta_{1}$, which measures the sensitivity of a physician's income to the amount of professional charges he generates. The coefficient, $\beta_{1}$, was significant ( $p<0.10$, two-tailed) for 90 percent of the groups. The proportion of a physician's compensation that is based on performance, denoted EST_RISK ${ }_{1}$, was then calculated for each group as:

Adjusted charges are the total amounts expected to be paid by patients or third party payers. Medical revenue is gross revenue net of refunds, returned checks, contractual discounts and allowances, bad debts and write-offs. Adjusted charges or medical revenues are not reported at the physician-level. Thus, gross charges is used as the performance measure for all firms that used any charge-based measure.

${ }^{13}$ Including only the 281 groups that used just a charge-based measure does not materially affect subsequent validity tests. 
The mean estimated proportion of performance-based compensation using (A-2) was 74 percent. Although values ranged from -125 percent to 250 percent, the majority of observations fell between 0 and 100 percent. Only 3 percent of firms had negative values for the estimated proportion of performance-based pay, and in most of these cases, the coefficient on physician charges, $\beta_{1}$, was not significant. The estimated proportion of performance-based pay exceeded 100 percent for 22 percent of the groups. There are two potential explanations for this. First, professional gross charges may not be the actual charge figure used in determining physician compensation. Second, factors besides charges, such as administrative responsibility, teaching responsibility, or research publications, may also indirectly affect compensation.

We also estimated performance-based compensation intensity for firms that used RVUs to determine physician compensation (EST_RISK 2$).{ }^{14}$ Only 38 of the 90 groups had sufficient data to calculate a coefficient for RVUs, $\beta_{1}$, which measures the sensitivity of a physician's income to the number of RVUs provided. The coefficient, $\beta_{1}$, was significant $(\mathrm{p}<0.10$ two-tailed) for 81 percent of these groups. The distribution of estimated risk ranged from 0 to $200 \%$, although the majority of observations fell between

\footnotetext{
${ }^{14} \mathrm{We}$ did not use patient encounters as a performance variable because encounters include ambulatory, hospital, and surgical/anesthesiology services. The intensity and duration of a patient encounter differs substantially across these 3 classifications. Thus, it is only feasible to measure income-encounter sensitivity within groups in which the proportion of each type of encounter is the same across physicians. However, few groups had consistent enough encounter patterns to estimate a reasonable number of incomeencounter sensitivities. Thus, patient encounters were not used to validate the reported compensation methodology. Furthermore, only 69 groups used patient encounters to evaluate physician performance, and of these 69 groups, all but 11 also used some other measure. This may reflect the difficulty in using encounters to evaluate a non-homogenous group of physicians.
} 
0 and $100 \%$. The estimated mean (median) proportion of performance-based compensation was 78 percent ( 72 percent).

\section{A.3 Comparison of estimated proportion of performance-based compensation to survey responses}

The estimated proportion of performance-based pay is compared to the actual compensation methodology reported using non-parametric correlations and traditional tests for differences in means. Since the proportion of performance-based pay may vary within a group, only groups in which at least 80 percent of the members are compensated with the same methodology are included in the validity tests. This reduces the sample size to 213 observations in the charge-based sample and 29 in the RVU-based sample. Table A-2 illustrates that the average estimated amount of performance-based pay by the actual compensation category reported in the survey. As expected, the mean estimated proportion of performance-based pay is increasing in the amount of performance-based pay reported. The non-parametric correlations between estimated risk and actual risk are $0.519(\mathrm{p}<0.01$, two-tail) and 0.795 ( $\mathrm{p}<0.01$, two-tail) for the charge-based and RVUbased sample respectively. Means tests of the between subject effects indicates that both estimates of the proportion of performance-based pay vary significantly by the actual risk category reported $(\mathrm{p}<0.01$, two-tail).

Finally, the validity of the categorical dependent variable is further investigated by computing the mean value of total compensation for each category of dependent variable. Agency theory posits that owners must pay agents more to induce the agent to accept greater risk. Accordingly, the mean level of compensation should be greatest when compensation is based entirely on performance. As illustrated in Table A-3, the 
mean level of compensation does increase as the risk category increases and mean level of compensation differs across categories.

Overall, our tests indicate that the self-reported proportion of performance-based compensation is consistent with the observed compensation payouts. Thus, we believe that the self-reported survey item is a valid measure for use in our empirical analysis. 
Table A-1

Measures used in determining physician compensation:

Use of Patient Encounters * Use of RVUs * Use of Charges

Cross-tabulation of $\mathbf{4 5 0}$ practices

\begin{tabular}{|c|c|c|c|c|c|}
\hline & & & Use & & \\
\hline & & & $\overline{\text { No }}$ & Yes & Total \\
\hline $\begin{array}{c}\text { Do not use } \\
\text { charges }\end{array}$ & $\begin{array}{r}\text { Use of Patient } \\
\text { Encounters }\end{array}$ & No & 63 & 37 & 100 \\
\hline & & Yes & $\underline{11}$ & $\underline{5}$ & $\underline{16}$ \\
\hline & & Total & 74 & 42 & 116 \\
\hline Use charges & Use of Patient & No & 242 & 39 & 281 \\
\hline & & Yes & 43 & $\underline{10}$ & $\underline{53}$ \\
\hline & & Total & 285 & 49 & 334 \\
\hline
\end{tabular}


Table A-2

Estimated proportion of performance-based compensation by actual category of performance-based compensation from the survey

\begin{tabular}{ccc}
\hline $\begin{array}{c}\text { FIRM_\%RISK: } \\
\text { Predominant method } \\
\text { of compensation for group } \\
\text { as reported in survey } \\
\text { question }\end{array}$ & $\begin{array}{c}\text { EST_RISK } 1 \text { Mean } \\
\text { proportion of } \\
\text { performance-based pay } \\
\text { estimated using charge- } \\
\text { based measures }\end{array}$ & $\begin{array}{c}\text { EST_RISK } 2 \text { Mean } \\
\text { estimated proportion of } \\
\text { performance-based pay } \\
\text { using RVUs }\end{array}$ \\
\hline $\begin{array}{c}\text { 100\% Straight Salary } \\
50 \% \text { to 99\% Salary }\end{array}$ & $.1973(\mathrm{n}=10)$ & $.4071(\mathrm{n}=5)$ \\
$50 \%$ to 99\% Productivity & $.7249(\mathrm{n}=65)$ & $.4867(\mathrm{n}=8)$ \\
$100 \%$ Productivity & $.9532(\mathrm{n}=5)$ & $.8970(\mathrm{n}=7)$ \\
& & $1.1306(\mathrm{n}=9)$ \\
All Categories & $.7607(\mathrm{n}=213)$ & $.7719(\mathrm{n}=29)$ \\
\hline
\end{tabular}


Table A-3

Mean level of compensation by actual category of performancebased pay reported in survey $(n=815)$

\begin{tabular}{cc}
\hline & $\begin{array}{c}\text { Average total compensation } \\
\text { for FTEs }>0.8 .\end{array}$ \\
\hline $100 \%$ Straight Salary & $\$ 194,695$ \\
$50 \%$ to $99 \%$ Salary & $\$ 210,820$ \\
$50 \%$ to $99 \%$ Productivity & $\$ 272.334$ \\
$100 \%$ Productivity & $\$ 283,159$ \\
Total & $\$ 243,771$ \\
ANOVA F-statistic & $20.54(\mathrm{p}<0.01$, two-tail $)$ \\
\hline
\end{tabular}




\section{References}

Alchain, Armen A., and Demsetz, Harold. "Production, Information Costs, and Economic Organization." American Economic Review. 62 (December 1972): 777-95.

Aggarwal, R. and Samwick, 1999. "The Other Side of the Trade-off: The Impact of Risk on Executive Compensation." Journal of Political Economy. 107(1), 65-105.

Alerlof , G. and L. Katz, 1989. "Workers Trust Funds and the Logic of Wage Profiles." Quarterly Journal of Economics. 104, 525-536.

Baker, George; M. Jensen, and K. Murphy, 1998. "Compensation and Incentives: Practice vs. Theory.” Journal of Finance. 43 (July): 593-616.

Banker, R. and S. Datar, 1989. "Sensitivity, Precision, and Linear Aggregation for Performance Evaluation.” Journal of Accounting Research. (Spring): 21-39.

Bizjak, J., J. Brickley and J. Coles, 1993. "Stock-based incentive compensation and investment behavior." Journal of Accounting and Economics. 16 (January/April/July): 349-72.

Bowers, M. R., Swan, J.E., and Koehler, W.F. "What Attributes Determine Quality and Satisfaction with Health Care Delivery." Health Care Management Review. 19, no 4 (1994): 49-55.

Bushman, Robert, Raffi Indjejikian, and Abbie Smith. 1996. "CEO compensation: The role of individual performance evaluation." Journal of Accounting and Economics. 21:161-193.

Cavalluzzo, K. and S. Sankaragururswamy, 2002. "Compensation, performance, ownership structure, and taxes: evidence from privately held small corporations." Working Paper. Georgetown University. June.

Debrock, L. and R. J. Arnould, 1993. "Utilization Controls in HMOs." Quarterly Review of Economics and Finance. Autumn 1993: 31-26.

Deckop, J. R., 1988. "Determinants of chief executive officer compensation." Industrial and Labor Relations Review 41 (January): 215-26.

Dynan, L. G.J. Bazzoli, and L. Burns. 1998. "Assessing the Extent of Integration Achieved Through Physician-Hospital Arrangements." Journal of Healthcare Management 43 (3) (May/June): 242-262.

Encinosa, William E. III, Martin Gaynor, and James B. Rebitzer, 1997. "The Sociology of Groups and The Economics of Incentives: Theory and Evidence on Compensation Systems." NBER Working Paper 5953, 1997. 
Ferral, C. 1996. "Promotions and Incentives in Partnerships: Evidence From Major U.S. Law Firms.” Canadian Journal of Economics 29 (4): 811-827.

Figliuolo, P. Mango, and D. McCormick, 2000. "Hospital, heal thyself." The Mckinsey Quarterly. 1, 91-97.

Garen, John E. 1994. "Executive Compensation and Principal-Agent Theory." Journal of Political Economy. 102, 1175-99.

Gaynor, Martin, 1989. "Competition within the Firm: Theory Plus Some Evidence from Medical Group Practice.” Rand J. Econ. 20, 59-76.

Gaynor and Gertler, 1995. "Moral hazard and risk spreading in partnerships." RAND J. of Economics Vol. 26, No. 3, 591-613.

Gaynor, M. and M. Pauly, 1990 "Comp and Productive Efficiency in Partnerships: Evidence from Medical Group Practice.” Journal of Political Economy. 98(3), 544-573.

Gaver, J. F., and K.M. Gaver. 1993. Additional evidence on the association between the investment opportunity set and corporate financing, dividend, and compensation policies. Journal of Accounting and Economics. 16 (January/April/July): 125-60.

Gill, T, and A Feinstein. "A Critical Appraisal of the Quality -of-Life Measurements." Journal of the American Medical Association. 272 (1994): 619-26.

Gompers, Paul and Josh Lerner, 1999. "An analysis of compensation in the U.S. venture capital partnerships." Journal of Financial Economics. 51(1), 3-44.

Hillman, A.L. "Health Maintenance Organizaitons, Financial Incentives, and Physician Judgements." Annals of Internal Medicine 112 (1990): 891-93.

Holmstrom, Bengt. 1979. "Moral Hazard and Observability.” Bell J. Econ. 10, 74-91.

Holmstrom, Bengt. 1982. "Moral Hazard in Teams." Bell J. Econ. 13 (Autumn): 324-40.

Holmstorm, B., and P. Milgrom, 1991. "Multitask Principal Agent Analyses: Incentive Contracts, Asset Ownership and Job Design." Journal of Law, Economics, and Organization. 7, 24-52.

Huber, P.J. 1967. "The Behavior of Miximum Likelihood Estimates Under Non-Standard Conditions." In Proceedings of the Fifth Berkeley Symposium in Mathemeatical Statistics and Probability. Berkeley, CA: University of California Press.

Huddart, S. and P. J. Liang. 2002. "Profit Sharing and Monitoring in Partnerships." Working paper, Pennsylvania State University and Carnegie Mellon University. 
Hurley, R., T. Lake, M. Gold, and D. Almond. "Arrangements Between Managed Care Plans and Physicians II." Report submitted to Physician Payment Review Commission. Mathematica Policy Research, Inc. June, 1996.

Kandel, Eugene and Edward P. Lazear, 1992. "Peer Pressure and Partnerships." Journal of Political Economy. 100(4) 801-817.

Ke, B., K. Petroni, and A. Safieddine, 1999. "Ownership concentration and sensitivity of executive accounting performance measures: evidence from publicly and privately held companies." Journal of Accounting and Economics. 28, 185-209.

Kennedy, K.M. and M.P. Buckley. 1997. "Matching Physician Compensation to Capitation Levels.” Healthcare Financial Management 51 (9) (September): 81-85.

Kirchheimer, B., 2000. "Physician regrouping." Modern Healthcare. Aug. 7, 44-48.

Lambert, R. and D. Larcker, 1987. "An Analysis of the Use of Accounting and Market Measures of Performance in Executive Compensation Contracts." Journal of Accounting Research. 25 Supplement, 179-203.

Lambert, R. A. and D. F. Larcker, "The Prospective Payment System, Hospital Efficiency, and Compensation Contracts for Senior-Level Hospital Administrators," Journal of Accounting and Public Policy, Vol. 14, No. 1. (Spring, 1995), pp. 1-31.

Landers, R., Rebitzer, and L. Taylor. 1996. "Rat Race Redux: Adverse Selection in the Determination of Work Hours in Law Firms." American Economic Review, 86(3),329349.

Lang, K and J. Gordon, 1995. "Partnerships as Insurance Devices: Theory and Evidence." Rand Journal of Economics, 26, 614-629.

Latham Consulting Group Medical Group Advisors, 2001 "Physician Compensation: The Search for Perfection." (www.lathamconsulting.com/SR-Compensation_1.htm).

Lee, Robert H.,1990. “Monitoring Physicians: A Bargaining Model of Medical Group Practice." Journal of Health Economics 9: 463-481.

Leonard, 1990. J. S. 1990. Executive pay and firm performance. Industrial and Labor Relations Review 43 (February): 13S-29S.

Leone, A.J. 2002. "The Relation Between Efficient Risk-Sharing Arrangements and Firm Characteristics: Evidence From the Managed Care Industry." Journal of Management Accounting Research 14 (Fall): 99-117.

Lewellen, Loderer, and Martin. 1987. Executive compensation and executive incentive problems: An empirical analysis. Journal of Accounting and Economics 9 (December): 287-310. 
Medical Group Management Association, 1999. "Physician Compensation and Production Survey: 1999 Report based on 1998 Data.” Englewood, CO.

Narayanan, V. G., 1995. "Moral Hazard in Repeated Professional Partnerships." Contemporary Accounting Research. 11(2) 895-917.

Newhouse, Joseph P. 1973. "The Economics of Group Practice.” J. Human Resources 8, $37-56$.

Pauly, Mark, 1996. "Economics of Multispecialty Group Practice." Journal of Ambulatory Care. 1996. 19(3). 26-33.

Pavlik, Ellen, Tomas Scott, Peter Tiessen. "Executive Compensation: Issues and Research.” Journal of Accounting Literature. Vol. 12, 1993, pp. 131-189.

Phelps, Charles E., 1997. Chapter 6, The Physician, pp 197-207. Health Economics, $2^{\text {nd }}$ Ed. 1992. Addison -Wesley.

Pontes, Manuel C., 1995. "Agency Theory: A Framework for Analyzing Physician Services." Health Care Management Review, Vol. 20 (4), Fall 1995, pp. 57-67.

Prendergast, Canice. 1999 "The Provision of Incentives in Firms.” Journal of Economic Literature. Vol. XXXVII (March), 7-63.

Reinhardt, Uwe E.; Pauly, Mark V.; and Held, Philip J. "Financial Incentives and the Economic Performance of Group Practitioners." In "Analysis of Economic Performance in Medical Group Practices.” Edited by Philip J. Held and Uwe E. Reinhardt. Project Report no. 79-05. Princeton, B.J. Mathematica Policy Research., 1979.

Schleifer and Vishny, 1997. "A Survey of Corporate Governance." Journal of Finance. $52,737-83$.

White, H. 1980. “A Heteroskedasticty-Consistent Covariance Matrix Estimator and a Direct Test of Heteroskedasticity." Econometrica 50, 1-25. 
Table 1

Descriptive statistics on medical group pay practices and organizational characteristics

Panel A: Physician pay practices ${ }^{1}$

\begin{tabular}{|c|c|c|c|c|c|c|}
\hline & \multicolumn{2}{|c|}{$\underline{\text { All physicians }}$} & \multicolumn{2}{|c|}{$\begin{array}{c}\text { Physicians } \\
\text { in member-owned groups }\end{array}$} & \multicolumn{2}{|c|}{$\begin{array}{c}\text { Physicians in } \\
\text { outside-owned groups }\end{array}$} \\
\hline & $\mathbf{N}$ & $\%$ & $\mathbf{N}$ & $\%$ & $\mathbf{N}$ & $\%$ \\
\hline 0\% bonus & 3,242 & $19 \%$ & 1,584 & $14 \%$ & 1,658 & $27 \%$ \\
\hline $1-50 \%$ bonus & 4,121 & $24 \%$ & 2,083 & $19 \%$ & 2,038 & $33 \%$ \\
\hline $51-99 \%$ bonus & 3,573 & $21 \%$ & 2,755 & $25 \%$ & 818 & $13 \%$ \\
\hline 100\% bonus & 5,723 & $33 \%$ & 4,049 & $36 \%$ & 1,674 & $27 \%$ \\
\hline Equal shares & 673 & $4 \%$ & 666 & $6 \%$ & 7 & $0 \%$ \\
\hline TOTAL & 17,332 & $100 \%$ & 11,137 & $100 \%$ & 6,195 & $100 \%$ \\
\hline
\end{tabular}

Panel B: Physician characteristics ${ }^{2}$

\begin{tabular}{|c|c|c|c|c|c|c|c|c|c|}
\hline & \multicolumn{3}{|c|}{ All physicians $(\mathrm{N}=17,332)$} & \multicolumn{3}{|c|}{$\begin{array}{c}\text { Physicians in } \\
\text { member-owned groups }(\mathrm{N}=11,137)\end{array}$} & \multicolumn{3}{|c|}{$\begin{array}{c}\text { Physicians in } \\
\text { outside-owned groups }(\mathrm{N}=6,195)\end{array}$} \\
\hline & Mean & Median & Std Dev. & Mean & Median & Std Dev. & Mean $^{4}$ & Median $^{5}$ & Std Dev. \\
\hline Total pay ${ }^{3}$ & $\$ 230,910$ & $\$ 185,000$ & $\$ 152,800$ & $\$ 258,409$ & $\$ 210,000$ & $\$ 170,690$ & $\$ 178,983^{* * *}$ & $\$ 152,209^{* * *}$ & $\$ 91,096$ \\
\hline Same specialty & 2.06 & 1.95 & 1.15 & 1.86 & 1.79 & 1.01 & $2.42 * * *$ & $2.30 * * *$ & 1.30 \\
\hline Primary care & $40.6 \%$ & & $49.1 \%$ & $29.9 \%$ & & & $59.8 \% * * *$ & & \\
\hline Non-surgical & $33.4 \%$ & & $47.2 \%$ & $38.5 \%$ & & & $24.3 \% * * *$ & & \\
\hline Surgical & $26.0 \%$ & & $43.8 \%$ & $31.6 \%$ & & & $15.9 \% * * *$ & & \\
\hline Experience (years) & 13.4 & 12.0 & 9.0 & 13.8 & 12.0 & 8.9 & $12.8 * * *$ & $11.0^{* * *}$ & 9.1 \\
\hline $\begin{array}{l}<=2 \text { years } \\
\text { experience } \\
3 \text {-to-5 years } \\
\text { experience }\end{array}$ & $8.0 \%$ & & $27.2 \%$ & $7.4 \%$ & & & $\begin{array}{l}9.1 \% * * * \\
16.3 \% * * *\end{array}$ & & \\
\hline Non-clinical activity & $5.2 \%$ & $0.0 \%$ & $14.8 \%$ & $4.4 \%$ & $0.0 \%$ & $14.0 \%$ & $6.6 \% * * *$ & $0.0 \% * * *$ & $15.9 \%$ \\
\hline
\end{tabular}


Table 1 (continued)

Panel C: Variation in group pay practices ${ }^{6}$

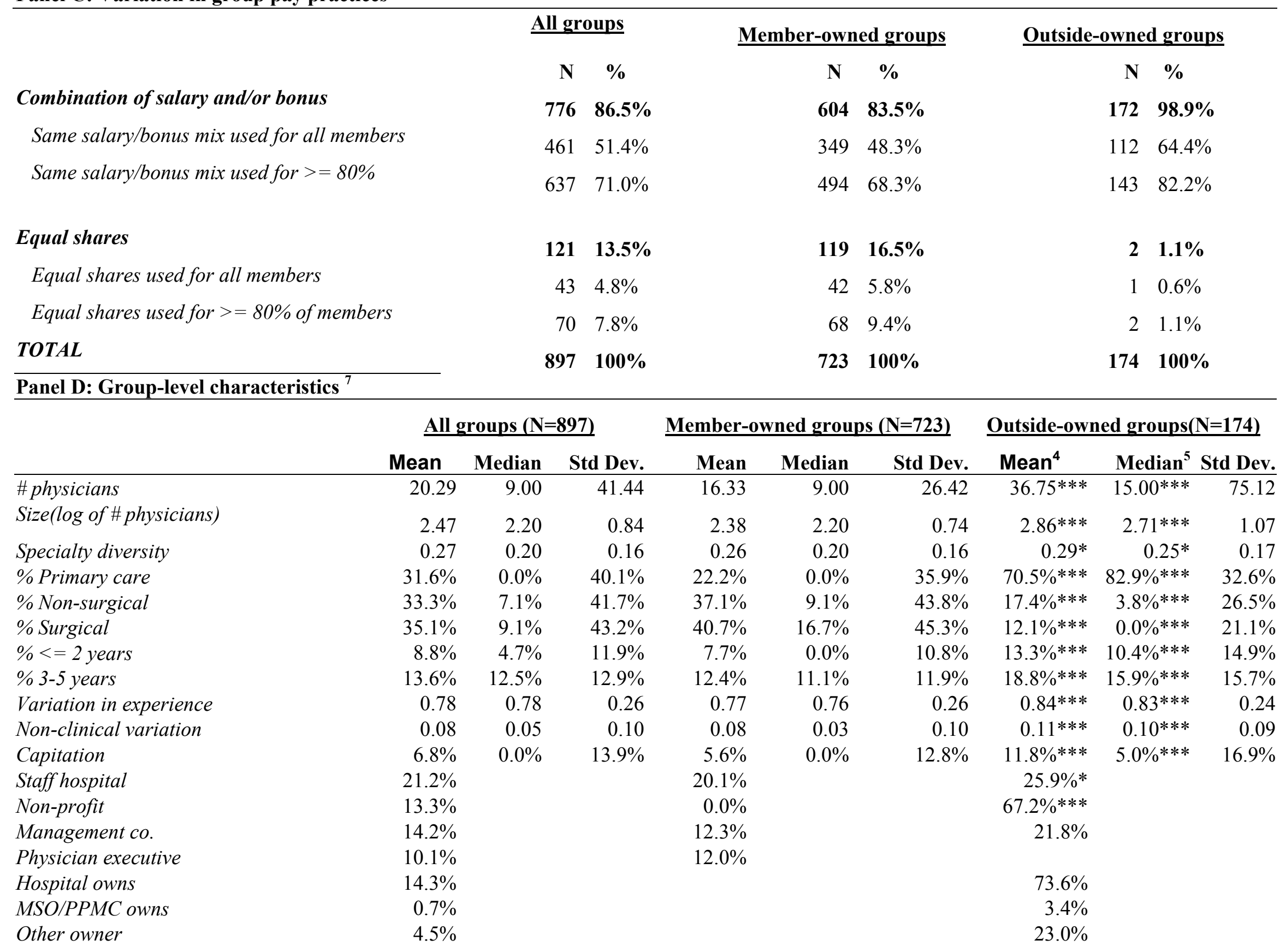




\section{Notes to Table 1}

${ }^{1}$ Physician pay practices are as follows: $0 \%$ bonus - None of the physician's compensation is derived from a bonus based upon individual performance, i.e., the physician's compensation is derived entirely from salary. $1-50 \%$ bonus $-1 \%$ to $50 \%$ of the physician's compensation is based upon individual performance, with the remainder derived from a fixed salary. $51-99 \%$ bonus $-51 \%$ to $99 \%$ of the physician's compensation is based upon individual performance, with the remainder derived from a fixed salary. $100 \%$ bonus - All of the physician's compensation is based upon individual performance. Equal shares - Proceeds of participating members are divided evenly among those members, irrespective of individual contribution.

${ }^{2}$ Physicians compensated on an equal shares basis are excluded from calculations. Definitions are as follows: Pay - Total annual compensation in dollars. Same specialty - Log of the number of physicians in the practice that have the same specialty as a physician. Primary care - Indicator variable that equals 1 if physician's specialty is primary care, and 0 otherwise. Non-surgical - Indicator variable that equals 1 if physician is a non-surgical specialist, and 0 otherwise. Surgical Indicator variable that equals 1 if physician is a surgical specialist, and 0 otherwise. $<=2$ years - Indicator variable that equals 1 if physician has 2 or less years experience, and 0 otherwise. 3-5 years - Indicator variable that equals 1 if physician has 3 to 5 years experience, and 0 otherwise. Non-clinical activity Percentage of time physician is engaged in non-clinical activities.

${ }^{3}$ Not all physicians supplied dollar amounts of compensation. Thus, full sample for total pay contains only 15,060 physicians vs. 16,659.

$4 * *, *$ indicate that null hypothesis of equal means for member-owned and outside-owned partitions can be rejected at significance level of $1 \%$ and $5 \%$ respectively.

$5 * *, *$ indicate that null hypothesis that member-owned and outside-owned partitions were drawn from same population can be rejected at significance level of $1 \%$ and $5 \%$ respectively.

${ }^{6}$ Combination of salary and/or bonus - Predominant method of compensation used by group (i.e., method used with highest percentage of members) is some combination of salary and bonus based upon individual performance. Various combinations of salary and bonus are detailed in Panel A. Same salary/bonus mix used with all members - The same combination of salary and bonus (for e.g., $30 \%$ salary and $70 \%$ bonus) is used with every member of the group. Same salary/bonus mix used with $>=80 \%$ - The same combination of salary and bonus is used with at least $80 \%$ of the group members. Equal shares - Proceeds of participating members are divided evenly among those members, irrespective of individual contribution. Equal shares used with all members - Every member of the group participates in equal shares distribution. Equal shares used with $>=80 \%$ of members - At least $80 \%$ of group members are compensating using equal shares For example, a 10-member group may have only 9 members that participate on an equal shares basis. In this case, the proceeds of the group are pooled and the net proceeds are distributed evenly among those 9 members, while the remaining member receives a salary and/or bonus based upon his/her individual performance.

${ }^{7}$ Group-level characteristics exclude groups in which equal shares is predominant method of compensation. Definitions are as follows: \% physicians with same salary/bonus mix - Percentage of group members that are compensated using the same combination of salary and bonus. \# physicians - number of physicians in the practice. Size - Log of the number of physicians in the practice. Specialty diversity - Number of different specialties in practice scaled by the number of physicians. Larger values indicate a more diverse mix of specialties. \% Primary care - Percentage of group members that practice primary care specialties. \% Non-surgical Percentage of group members that practice non-surgical specialties \% Surgical-Percentage of group members that practice surgical specialties. \% $<=2$ years Percentage of group members with 2 or fewer years experience. \% 3-5 years - Percentage of group members with 3-to-5 years of experience. Staff hospital Indicator variable that equals 1 if practice staffs a hospital department, and 0 otherwise. Capitation- Percentage of a practice's patients that are covered by capitation insurance programs. Management co. - Indicator variable that equals 1 if practice uses an MSO or PPMC, and 0 otherwise. Physician executive - Indicator variable that equals 1 if practice has appointed a physician-member to manage the group. Hospital owns, MSO/PPMC owns, and other owner are indicator variables that equal 1 if the practice is owned by a hospital/health system, management service organization/physician practice management company, or some other outside owner, respectively, and 0 otherwise. Non-profit - Indicator variable that equals 1 if the entity that owns practice is a not-for-profit entity, and 0 otherwise. 
Table 2

Pearson correlations ${ }^{1,2,3}$

$\mathrm{N}=16,659$ physicians

\begin{tabular}{|c|c|c|c|c|c|c|c|c|c|c|}
\hline & Capitation & Size & $\begin{array}{r}\text { Same } \\
\text { specialty }\end{array}$ & $\begin{array}{r}\text { Non- } \\
\text { surgical }\end{array}$ & Surgical & $\begin{array}{r}\text { Staff } \\
\text { hospital }\end{array}$ & $<=2$ years & 3-5 years & $\begin{array}{l}\text { Non- } \\
\text { clinical }\end{array}$ & $\begin{array}{l}\text { Manage- } \\
\text { ment co. }\end{array}$ \\
\hline Size & $\begin{array}{r}0.40 \\
(0.00)\end{array}$ & 1.00 & & & & & & & & \\
\hline Same specialty & $\begin{array}{r}0.13 \\
(0.00)\end{array}$ & $\begin{array}{r}0.44 \\
(0.00)\end{array}$ & 1.00 & & & & & & & \\
\hline Non-surgical & $\begin{array}{l}-0.01 \\
(0.29)\end{array}$ & $\begin{array}{r}0.06 \\
(0.00)\end{array}$ & $\begin{array}{c}-0.19 \\
(0.00)\end{array}$ & 1.00 & & & & & & \\
\hline Surgical & $\begin{array}{l}-0.09 \\
(0.00)\end{array}$ & $\begin{array}{l}-0.17 \\
(0.00)\end{array}$ & $\begin{array}{c}-0.28 \\
(0.00)\end{array}$ & $\begin{array}{r}-0.41 \\
(0.00)\end{array}$ & 1.00 & & & & & \\
\hline Staff hospital & $\begin{array}{r}0.23 \\
(0.00)\end{array}$ & $\begin{array}{r}0.38 \\
(0.00)\end{array}$ & $\begin{array}{r}0.15 \\
(0.00)\end{array}$ & $\begin{array}{r}0.19 \\
(0.00)\end{array}$ & $\begin{array}{r}-0.10 \\
(0.00)\end{array}$ & 1.00 & & & & \\
\hline$<=2$ years & $\begin{array}{r}-0.01 \\
(0.49)\end{array}$ & $\begin{array}{l}-0.04 \\
(0.00)\end{array}$ & $\begin{array}{l}-0.03 \\
(0.00)\end{array}$ & $\begin{array}{l}-0.05 \\
(0.00)\end{array}$ & $\begin{array}{r}-0.02 \\
(0.02)\end{array}$ & $\begin{array}{l}-0.03 \\
(0.00)\end{array}$ & 1.00 & & & \\
\hline 3-5 years & $\begin{array}{r}-0.01 \\
(0.45)\end{array}$ & $\begin{array}{r}-0.01 \\
(0.06)\end{array}$ & $\begin{array}{r}-0.01 \\
(0.13)\end{array}$ & $\begin{array}{r}0.00 \\
(0.84)\end{array}$ & $\begin{array}{r}-0.02 \\
(0.00)\end{array}$ & $\begin{array}{r}-0.01 \\
(0.05)\end{array}$ & $\begin{array}{r}-0.12 \\
(0.00)\end{array}$ & 1.00 & & \\
\hline Non-clinical & $\begin{array}{r}-0.01 \\
(0.21)\end{array}$ & $\begin{array}{r}0.02 \\
(0.00)\end{array}$ & $\begin{array}{r}0.03 \\
(0.00)\end{array}$ & $\begin{array}{r}0.02 \\
(0.01)\end{array}$ & $\begin{array}{r}-0.06 \\
(0.00)\end{array}$ & $\begin{array}{r}0.05 \\
(0.00)\end{array}$ & $\begin{array}{r}0.01 \\
(0.12)\end{array}$ & $\begin{array}{r}-0.01 \\
(0.48)\end{array}$ & 1.00 & \\
\hline $\begin{array}{l}\text { Management } \\
\text { co. }\end{array}$ & $\begin{array}{r}0.19 \\
(0.00)\end{array}$ & $\begin{array}{r}0.18 \\
(0.00)\end{array}$ & $\begin{array}{r}0.03 \\
(0.00)\end{array}$ & $\begin{array}{l}-0.01 \\
(0.15)\end{array}$ & $\begin{array}{r}-0.03 \\
(0.00)\end{array}$ & $\begin{array}{r}0.11 \\
(0.00)\end{array}$ & $\begin{array}{r}0.01 \\
(0.14)\end{array}$ & $\begin{array}{r}-0.02 \\
(0.01)\end{array}$ & $\begin{array}{r}0.01 \\
(0.30)\end{array}$ & 1.00 \\
\hline & 0.07 & 0.00 & 0.02 & 0.05 & -0.02 & -0.01 & 0.01 & -0.01 & -0.01 & -0.07 \\
\hline $\begin{array}{l}\text { Physician } \\
\text { executive }\end{array}$ & $\begin{array}{r}(0.00) \\
0.40 \\
\end{array}$ & $\begin{array}{r}(0.92) \\
1.00 \\
\end{array}$ & $(0.00)$ & $(0.00)$ & $(0.01)$ & $(0.51)$ & $(0.19)$ & $(0.08)$ & $(0.23)$ & $(0.00)$ \\
\hline
\end{tabular}




\section{Notes to Table 2}

${ }^{1}$ Two-tailed significance levels are in ( ) below correlation coefficient.

${ }^{2}$ Correlation coefficients do not vary significantly when sample is partitioned into member-owned and outside-owned practices.

${ }^{3}$ Variable definitions: Capitation - Percentage of a practice's patients that are covered by capitation insurance programs. Size - Log of the number of physicians in the practice. Same specialty - Log of the number of physicians in the practice that have the same specialty as a physician. Non-surgicalIndicator variable that equals 1 if physician is a non-surgical specialist, and 0 otherwise. Surgical - Indicator variable that equals 1 if physician is a surgical specialist, and 0 otherwise. Staff hospital - Indicator variable that equals 1 if practice staffs a hospital department, and 0 otherwise. $<=2$ years-Indicator variable that equals 1 if physician has 2 or less years of experience, and 0 otherwise. 3-5 years - Indicator variable that equals 1 if physician has 3 to 5 years of experience, and 0 otherwise. Non-clinical - Percentage of time physician is engaged in non-clinical activities. Management co. - Practice engages the services of a MSO or PPMC. Physician executive - Practice has appointed a physician-member to manage the group. 
Table 3

Performance-based compensation as a percentage of total individual pay ${ }^{1}$

\begin{tabular}{|c|c|c|c|c|c|}
\hline \multirow{3}{*}{$\frac{\text { Variable }^{2}}{\text { Constant }}$} & \multirow{3}{*}{ Predicted sign } & \multicolumn{2}{|c|}{$\underline{\text { Member-owned practices }}$} & \multicolumn{2}{|c|}{ Outside-owned practices } \\
\hline & & \multicolumn{2}{|c|}{ Coefficient (t-stat) } & \multicolumn{2}{|c|}{ Coefficient (t-stat) } \\
\hline & & $\begin{array}{r}93.12 \\
(13.59)\end{array}$ & $* * *$ & $\begin{array}{r}71.98 \\
(6.00)\end{array}$ & $* * *$ \\
\hline \multicolumn{6}{|l|}{ Goal congruence } \\
\hline Capitation & - & $\begin{array}{l}-45.43 \\
(-6.65)\end{array}$ & $* * *$ & $\begin{array}{r}-3.94 \\
(-0.19)\end{array}$ & \\
\hline \multicolumn{6}{|l|}{ Informativeness } \\
\hline Staff hospital & - & $\begin{array}{l}-15.42 \\
(-4.19)\end{array}$ & $* * *$ & $\begin{array}{r}-9.00 \\
(-1.20)\end{array}$ & \\
\hline$<=2$ years & - & $\begin{array}{r}-27.56 \\
(-11.77)\end{array}$ & $* * *$ & $\begin{array}{l}-15.02 \\
(-4.01)\end{array}$ & $* * *$ \\
\hline 3-5 years & - & $\begin{array}{r}-9.00 \\
(-7.19)\end{array}$ & $* * *$ & $\begin{array}{r}-5.00 \\
(-2.61)\end{array}$ & $* * *$ \\
\hline Non-clinical & - & $\begin{array}{l}-14.01 \\
(-3.11)\end{array}$ & $* * *$ & $\begin{array}{l}-12.41 \\
(-2.42)\end{array}$ & $* *$ \\
\hline \multicolumn{6}{|l|}{ Monitoring ability } \\
\hline Size & $+/-$ & $\begin{array}{r}4.37 \\
(2.93)\end{array}$ & $* * *$ & $\begin{array}{r}2.21 \\
(0.98)\end{array}$ & \\
\hline Same specialty & - & $\begin{array}{r}-3.02 \\
(-2.35)\end{array}$ & $* *$ & $\begin{array}{r}-3.19 \\
(-1.58)\end{array}$ & \\
\hline Non-surgical & + & $\begin{array}{l}-12.60 \\
(-4.63)\end{array}$ & $* * *$ & $\begin{array}{r}-6.61 \\
(-1.57)\end{array}$ & \\
\hline Surgical & + & $\begin{array}{r}0.51 \\
(0.21)\end{array}$ & & $\begin{array}{r}-3.74 \\
(-1.15)\end{array}$ & \\
\hline Management co. & - & $\begin{array}{r}8.60 \\
(2.16)\end{array}$ & $* *$ & $\begin{array}{r}-5.76 \\
(-0.72)\end{array}$ & \\
\hline Physician executive & - & $\begin{array}{r}1.20 \\
(0.28)\end{array}$ & & & \\
\hline MSO/PPMC owns & & & & $\begin{array}{l}12.38 \\
(1.31)\end{array}$ & \\
\hline Other owner & & & & $\begin{array}{l}-29.94 \\
(-3.36)\end{array}$ & $* * *$ \\
\hline
\end{tabular}


Table 3, continued

\begin{tabular}{|c|c|c|c|c|}
\hline \multirow{2}{*}{$\begin{array}{l}\text { Control variables }^{4} \\
\text { Non-profit }\end{array}$} & \multicolumn{2}{|c|}{ Member-owned practices } & \multicolumn{2}{|c|}{ Outside-owned practices } \\
\hline & & & $\begin{array}{r}2.34 \\
(0.39)\end{array}$ & \\
\hline Suburb & $\begin{array}{l}-11.68 \\
(-3.10)\end{array}$ & $* * *$ & $\begin{array}{r}-7.04 \\
(-0.94)\end{array}$ & \\
\hline Rural & $\begin{array}{l}-14.26 \\
(-3.70)\end{array}$ & $* * *$ & $\begin{array}{l}15.07 \\
(1.82)\end{array}$ & $*$ \\
\hline Northeast & $\begin{array}{l}-29.05 \\
(-2.84)\end{array}$ & $* * *$ & $\begin{array}{l}-25.66 \\
(-2.44)\end{array}$ & $* *$ \\
\hline North Atlantic & $\begin{array}{l}-36.64 \\
(-5.45)\end{array}$ & $* * *$ & $\begin{array}{l}-52.81 \\
(-4.48)\end{array}$ & $* * *$ \\
\hline Mid Atlantic & $\begin{array}{l}-20.97 \\
(-2.83)\end{array}$ & $* * *$ & $\begin{array}{l}-39.93 \\
(-3.95)\end{array}$ & \\
\hline Rocky mountain & $\begin{array}{l}-11.52 \\
(-2.25)\end{array}$ & $* *$ & $\begin{array}{l}-18.03 \\
(-1.69)\end{array}$ & $*$ \\
\hline Northwest & $\begin{array}{r}6.51 \\
(1.59)\end{array}$ & & $\begin{array}{l}-23.79 \\
(-1.84)\end{array}$ & * \\
\hline Southwest & $\begin{array}{r}-6.99 \\
(-1.68)\end{array}$ & $*$ & $\begin{array}{l}-20.91 \\
(-2.36)\end{array}$ & $* *$ \\
\hline Eastern Midwest & $\begin{array}{l}-10.19 \\
(-2.48)\end{array}$ & & $\begin{array}{l}-30.89 \\
(-3.80)\end{array}$ & $* * *$ \\
\hline Lower Midwest & $\begin{array}{r}-9.82 \\
(-1.90)\end{array}$ & $*$ & $\begin{array}{l}-12.97 \\
(-0.87)\end{array}$ & \\
\hline Southern $C A$ & $\begin{array}{r}0.38 \\
(0.05)\end{array}$ & & & \\
\hline Northern $C A$ & $\begin{array}{r}-4.31 \\
(-0.26)\end{array}$ & & $\begin{array}{l}18.86 \\
(2.38)\end{array}$ & $* *$ \\
\hline Number of physicians & 10,471 & & 6,188 & \\
\hline Number of practices & 681 & & 173 & \\
\hline F-statistic & 25.1 & $* * *$ & 34.57 & $* * *$ \\
\hline R-squared ${ }^{4}$ & $30.50 \%$ & & $46.31 \%$ & \\
\hline
\end{tabular}




\footnotetext{
${ }^{1}$ Dependent variable is the percentage of a physician's total pay that is based upon individual performance, i.e., bonus as percentage of total compensation. The bonus portion can constitute $0 \%, 25 \%, 75 \%$, or $100 \%$ of compensation.

${ }^{2}$ Variable definitions: Capitation - Percentage of a practice's patients that are covered by capitation insurance programs. Size - Log of the number of physicians in the practice. Same specialty - Log of the number of other physicians in the practice that have the same specialty as a physician. Non-surgical - Indicator variable that equals 1 if physician is a nonsurgical specialist, and 0 otherwise. Surgical - Indicator variable that equals 1 if physician is a surgical specialist, and 0 otherwise. Staff hospital - Indicator variable that equals 1 if practice staffs a hospital department, and 0 otherwise. $<=2$ years -Indicator variable that equals 1 if physician has 2 or less years experience, and 0 otherwise. 3-5 years - Indicator variable that equals 1 if physician has 3 to 5 years experience, and 0 otherwise. Non-clinical - Percentage of time physician is engaged in non-clinical activities. Physician executive - Practice has appointed a physician member to manage the group. Management co. - Practice engages the services of a MSO or PPMC. Hospital owns, MSO/PPMC owns, and other owner are indicator variables that equal 1 if the practice is owned by a hospital/health system, management service organization/physician practice management company, or some other outside owner, respectively, and 0 otherwise. Non-profit - Indicator variable that equals 1 if the entity that owns practice is a not-for-profit entity, and 0 otherwise.

${ }^{3}$ Indicator variables for metropolitan area and region. Missing area variable is urban. Missing region is Upper Midwest. No outside-owned practices in the sample are located in Southern California.

${ }^{4}$ If control variables are removed from models, values for r-square drop to $22.5 \%$ for member-owned firms and $28.3 \%$ for outside-owned firms.

$*, * *$, and $* * *$ indicate two-tailed significance levels for test statistics of $10 \%, 5 \%$ and $1 \%$, respectively.
} 
Table 4

Intra-firm variation in the use of salary and bonus ${ }^{1}$

\begin{tabular}{|c|c|c|c|c|c|}
\hline \multirow[b]{3}{*}{ Variable $^{4}$} & \multirow[b]{3}{*}{ ted sign } & \multicolumn{2}{|c|}{$\begin{array}{c}\text { Model } 1 \text { (Logit model) } \\
\text { Same salary/bonus mix used } \\
\text { for all physicians in practice }{ }^{2}\end{array}$} & \multicolumn{2}{|c|}{$\begin{array}{c}\text { Model } 2 \text { (OLS model) } \\
\% \text { of physicians in practice } \\
\text { with same salary/bonus mix }{ }^{3} \\
\end{array}$} \\
\hline & & Member-owned & Outside-owned & Member-owned & Outside-owned \\
\hline & & \multicolumn{2}{|c|}{ Coefficient (Wald statistic) } & \multicolumn{2}{|c|}{ Coefficient (t-statistic) } \\
\hline Constant & & $\begin{array}{l}3.18^{* * *} \\
(22.27)\end{array}$ & $\begin{array}{l}3.08 * * * \\
(3.92)\end{array}$ & $\begin{array}{l}1.00^{* * *} \\
(34.34)\end{array}$ & $\begin{array}{l}1.06^{* * *} \\
(17.39)\end{array}$ \\
\hline \multicolumn{6}{|l|}{ Goal congruence } \\
\hline Capitation & & $\begin{array}{r}0.53 \\
(0.45)\end{array}$ & $\begin{array}{r}0.42 \\
(0.12)\end{array}$ & $\begin{array}{r}0.003 \\
(0.06)\end{array}$ & $\begin{array}{l}0.11^{*} \\
(1.77)\end{array}$ \\
\hline \multicolumn{6}{|l|}{ Informativeness } \\
\hline Staff hospital & + & $\begin{array}{l}0.44^{*} \\
(2.84)\end{array}$ & $\begin{array}{r}-0.14 \\
(-0.08)\end{array}$ & $\begin{array}{l}0.026^{*} \\
(1.84)\end{array}$ & $\begin{array}{r}-0.02 \\
(-0.80)\end{array}$ \\
\hline$\%<=2$ years & - & $\begin{array}{r}-1.15 \\
(-0.73)\end{array}$ & $\begin{array}{r}-1.99 \\
(-1.83)\end{array}$ & $\begin{array}{l}-0.215^{* * *} \\
(-2.84)\end{array}$ & $\begin{array}{l}-0.17 * * * \\
(-2.27)\end{array}$ \\
\hline$\%$ 3-5 years & - & $\begin{array}{r}0.21 \\
(0.06)\end{array}$ & $\begin{array}{r}0.14 \\
(0.01)\end{array}$ & $\begin{array}{l}-0.086^{*} \\
(-1.88)\end{array}$ & $\begin{array}{r}0.02 \\
(0.28)\end{array}$ \\
\hline $\begin{array}{l}\text { Variation in } \\
\text { experience }\end{array}$ & - & $\begin{array}{l}-1.22^{* *} \\
(-4.47)\end{array}$ & $\begin{array}{r}0.18 \\
(0.04)\end{array}$ & $\begin{array}{l}-0.021 \\
(-0.67)\end{array}$ & $\begin{array}{r}0.01 \\
(0.30)\end{array}$ \\
\hline Non-clinical variation & - & $\begin{array}{l}-3.87^{* * *} \\
(-16.69)\end{array}$ & $\begin{array}{r}-1.86 \\
(-0.66)\end{array}$ & $\begin{array}{l}-0.319^{* * *} \\
(-6.25)\end{array}$ & $\begin{array}{r}-0.09 \\
(-0.81)\end{array}$ \\
\hline \multicolumn{6}{|l|}{ Monitoring ability } \\
\hline $\operatorname{Size}^{5}$ & $+/-$ & $\begin{array}{l}-0.61 * * * \\
(-20.97)\end{array}$ & $\begin{array}{l}-0.78 * * * \\
(-10.65)\end{array}$ & $\begin{array}{l}-0.008 \\
(-1.17)\end{array}$ & $\begin{array}{l}-0.04 * * * \\
(-3.50)\end{array}$ \\
\hline Specialty diversity & - & $\begin{array}{l}-1.73^{* * *} \\
(-9.02)\end{array}$ & $\begin{array}{l}-4.16 * * * \\
(-8.09)\end{array}$ & $\begin{array}{l}-0.077^{* * *} \\
(-2.46)\end{array}$ & $\begin{array}{l}-0.19 * * * \\
(-2.67)\end{array}$ \\
\hline$\%$ Non-surgical & + & $\begin{array}{l}0.65^{*} \\
(3.58)\end{array}$ & $\begin{array}{r}0.78 \\
(0.86)\end{array}$ & $\begin{array}{r}0.019 \\
(1.19)\end{array}$ & $\begin{array}{r}0.00 \\
(0.05)\end{array}$ \\
\hline$\%$ Surgical & + & $\begin{array}{l}0.69^{* *} \\
(5.28)\end{array}$ & $\begin{array}{r}-0.32 \\
(-0.10)\end{array}$ & $\begin{array}{r}0.026 \\
(1.47)\end{array}$ & $\begin{array}{r}0.05 \\
(1.22)\end{array}$ \\
\hline Management co. & & $\begin{array}{r}-0.37 \\
(-1.64)\end{array}$ & $\begin{array}{r}0.37 \\
(0.46)\end{array}$ & $\begin{array}{l}-0.010 \\
(-0.63)\end{array}$ & $\begin{array}{r}0.02 \\
(0.76)\end{array}$ \\
\hline Physician executive & & $\begin{array}{r}0.09 \\
(0.10)\end{array}$ & & $\begin{array}{l}-0.015 \\
(-0.94)\end{array}$ & \\
\hline MSO/PPMC owns & & & $\begin{array}{r}-0.43 \\
(-0.13)\end{array}$ & & $\begin{array}{r}0.87 \\
(0.16)\end{array}$ \\
\hline Other owner & & & $\begin{array}{r}0.50 \\
(1.00)\end{array}$ & & $\begin{array}{r}0.53 \\
(0.63)\end{array}$ \\
\hline Number of practices ${ }^{7}$ & & 604 & 172 & 604 & 172 \\
\hline $\begin{array}{l}\text { Negelkerke or Adj. } R \\
\text { Chi square or F statis }\end{array}$ & Iare & $\begin{array}{l}22.7 \% \\
111.7 * * *\end{array}$ & $\begin{array}{l}31.8 \% \\
45.1 * * *\end{array}$ & $\begin{array}{l}13.47 \% \\
8.83 * * *\end{array}$ & $\begin{array}{l}6.91 \% \\
1.91 * * *\end{array}$ \\
\hline
\end{tabular}




\section{Notes to Table 4}

${ }^{1}$ The analyses include only firms whose predominant method of compensation is a combination of salary and bonus. Firms that predominantly use equal shares (119 member-owned and 2 outside-owned firms) are excluded from this analysis. Including these firms reduces the significance of $\%$ surgical and $\%$ staff hospital, but does not materially impact our conclusions.

${ }^{2}$ Logistic regression. Dependent variable equals 1 (349 firms) if every group member receives the same combination of salary and/or bonus and 0 otherwise (255 firms). We also repeated the analysis after recoding the dependent variable to equal 1 if at least $80 \%$ of a groups members receive the same combination of salary and/or bonus, and 0 otherwise. This reduced the significance of the \% non-surgical, \% surgical and \% staff hospital variables, but did not materially affect our conclusions.

${ }^{3}$ Ordinary least squares regression. Dependent variable is the percentage of group members that receive the same combination of salary and/or bonus. Higher values indicate greater intra-group uniformity in compensation.

${ }^{4}$ Independent variables: Specialty concentration - Number of different specialties in group scaled by the number of group members (smaller values indicate greater diversity in specialties). \% Non-surgical - \% of group members in nonsurgical specialties. \% Surgical - \% of group members in a surgical specialties. Staff hospital - Indicator variable that equals 1 if practice staffs a hospital department, and 0 otherwise. $\%<=2$ years $-\%$ of group members with less than 2 years experience. $\%$ 3-5 years - \% of group members with 3 to 5 years of experience. Variation in experiencestandard deviation of group members' experience. Non-clinical variation - Standard deviation of the percentage of time group members are engaged in non-clinical activities. Capitation - Percentage of a practice's patients that are covered by capitation insurance programs. Size - Log of the number of physicians in the practice. Management co.-Practice has engaged the services of a MSO or PPMC. Physician executive - Practice has appointed a physician-member to manage the group. Hospital owns, MSO/PPMC owns, and other owner are indicator variables that equal 1 if the practice is owned by a hospital/health system, management service organization/physician practice management company, or some other outside owner that is not a hospital/health system or MSO/PPMC, respectively, and 0 otherwise. Non-profitIndicator variable that equals 1 if the entity that owns practice organizes as a not-for-profit, and 0 otherwise.

${ }^{5} \mathrm{We}$ also used indicator variables to compare intra-firm variation in compensation for firms with 5-7 members and 8-10 members to firms with more than 10 members. Intra-firm variation in compensation is significantly lower ( $\mathrm{p}<0.01$, two-tailed) firms with 5-7 members and 8-10 members when compare to firms with more than 10 members. This is consistent with the result for size, in which intra-firm variation in compensation methodology is increasing in firm size.

${ }^{6}$ Controls for metropolitan area and geographic region were included in the logistic regression, but are not shown in the table. Controls for metropolitan area and geographic region were not included in the OLS regression because did not statistically significantly improve the models fit.

${ }^{6}$ The number of firms $(604+172=776)$ does not agree with the number of firms in the physician-level analysis (Table 3: $682+173=855$ ) because 244 physicians that receive a salary/bonus mix, and hence are included in the physicianlevel analysis, work in 125 firms that predominantly use equal shares, and thus are excluded from this analysis.

${ }^{7}$ Change in R-square and F-statistic if control variables for metropolitan location and geographical region (suburban, rural, Northeast, etc.) are included in the OLS model.

$*, * *$, and $* * *$ indicate two-tailed significance levels of $10 \%, 5 \%$ and $1 \%$, respectively. "n.s." not significant at a level of $10 \%$ or better. 


\section{Table 5}

Use of team-based (equal shares) vs. individual-based (salary/bonus) compensation in member-owned firms (logit model) ${ }^{1,2}$

\begin{tabular}{|c|c|c|c|c|}
\hline & & $\begin{array}{c}\text { Model } 1 \\
\text { Predominantly ES vs } \\
\text { Predominantly S/B }\end{array}$ & $\begin{array}{c}\text { Model } 2 \\
100 \% \text { ES vs. } \\
100 \% \text { same S/B mix }\end{array}$ & $\begin{array}{c}\text { Model } 3 \\
100 \% \text { ES vs. } \\
100 \% \text { All Bonus } \\
\end{array}$ \\
\hline Variable $^{3}$ & Predicted & Coeff (Wald statistic) & Coeff (Wald statistic) & Coeff (Wald statistic) \\
\hline
\end{tabular}

\section{Constant}

$\begin{array}{rrr}-1.41 & 0.90 & 2.81 \\ (1.60) & (0.27) & (1.49)\end{array}$

\section{Goal congruence}

Capitation

$\begin{array}{rrr}-0.86 & -1.80 & -4.29 \\ (0.47) & (0.50) & (1.39)\end{array}$

\section{Informativeness}

\begin{tabular}{|c|c|c|c|c|}
\hline Staff hospital & + & $\begin{array}{l}-0.11 \\
(0.16)\end{array}$ & $\begin{array}{l}-0.58 \\
(1.32)\end{array}$ & $\begin{array}{l}-1.32 * \\
(3.44)\end{array}$ \\
\hline \multirow[t]{2}{*}{$\%<=2$ years } & - & $2.19 *$ & 0.81 & -0.58 \\
\hline & & $(2.86)$ & $(0.15)$ & $(0.03)$ \\
\hline \multirow[t]{2}{*}{$\% 3-5$ years } & - & -0.04 & 1.12 & 0.89 \\
\hline & & $(0.00)$ & $(0.43)$ & $(0.13)$ \\
\hline \multirow[t]{2}{*}{ Variation in experience } & - & $-1.06 * * *$ & $-3.36 * * *$ & $-3.42 * *$ \\
\hline & & $(12.05)$ & $(5.64)$ & $(5.64)$ \\
\hline \multirow[t]{2}{*}{ Non-clinical variation } & - & -0.86 & -1.80 & -4.29 \\
\hline & & $(0.47)$ & $(0.50)$ & $(1.39)$ \\
\hline \multicolumn{5}{|l|}{ Monitoring ability } \\
\hline \multirow[t]{2}{*}{$S i z e^{4}$} & - & -0.32 & -0.27 & 0.01 \\
\hline & & $(2.70)$ & $(0.56)$ & $(0.00)$ \\
\hline \multirow[t]{2}{*}{ Specialty diversity } & - & $-4.16 * * *$ & $-5.69 * * *$ & -3.84 \\
\hline & & $(15.13)$ & $(6.98)$ & $(1.39)$ \\
\hline \multirow[t]{2}{*}{$\%$ Non-surgical } & + & $2.72 * * *$ & $1.81 * *$ & 1.43 \\
\hline & & $(22.82)$ & $(4.46)$ & $(1.22)$ \\
\hline \multirow[t]{2}{*}{$\%$ Surgical } & + & $1.47 * * *$ & 0.76 & 1.42 \\
\hline & & $(6.84)$ & $(0.84)$ & $(1.41)$ \\
\hline \multirow[t]{2}{*}{ Management Co. } & & 1.28 & 2.66 & 3.72 \\
\hline & & $(1.16)$ & $(2.29)$ & $(1.83)$ \\
\hline \multirow[t]{2}{*}{ Physician executive } & & 0.39 & 0.23 & 0.88 \\
\hline & & $(1.28)$ & $(0.13)$ & $(0.90)$ \\
\hline \multicolumn{2}{|l|}{ Number of practices } & 723 & 391 & 179 \\
\hline \multirow{2}{*}{$\begin{array}{l}\text { Negelkerke R-square } \\
\text { Chi-Squared }\end{array}$} & & $26.06 \%$ & $26.30 \%$ & $38.50 \%$ \\
\hline & & 120.95 & 54.38 & 32.52 \\
\hline
\end{tabular}


Notes to Table 5

${ }^{1}$ Model 1 includes all firms. Dependent variable equals 1 if predominant method of compensation (i.e., form used most often) is equal shares (119 firms), and 0 if predominant method of compensation is some combination of salary and/or bonus (604 firms). In all but one case, predominant method of compensation is used with at least $50 \%$ of the group members.

Model 2 includes only firms that compensate all members using equal shares and those that use the same salary/bonus combination with all members. The dependent variable is equals 1 if $100 \%$ of the group members are compensated using equal shares (42 firms), and 0 if $100 \%$ of group members are compensated using the same mix of salary and bonus (349 firms). Firms that vary compensation by member are excluded from this analysis.

Model 3 includes only firms that compensate all members using equal shares and those that compensate all members with $100 \%$ bonus. The dependent variable equals 1 if $100 \%$ of the group members are compensated using equal shares (42 firms), and 0 if 100\% of group members' compensation is entirely based upon individual performance or bonus (54 firms). Firms that vary compensation member and firms that use a method other than equal shares or $100 \%$ performance-based bonus are excluded.

${ }^{2}$ Of the 121 practices that use equal shares, only 2 of these practices are outside-owned. Hence, corresponding model for outside-owned practices is not significant and is not shown.

${ }^{3}$ Independent variables: Size - Log of the number of physicians in the practice. Specialty concentration - Number of different specialties in group scaled by the number of group members (smaller numbers indicate greater diversity in specialties among group numbers). \% Non-surgical - \% of group members in a non-surgical specialty. \% Surgical$\%$ of group members in a surgical specialty. Staff hospital - Indicator variable that equals 1 if practice staffs a hospital department, and 0 otherwise. Variation in experience - standard deviation of group members experience. \% $<=2$ years $-\%$ of group members with less than 2 years experience. $\% 3-5$ years $-\%$ of group members with 3 to 5 years of experience. Non-clinical variation - Standard deviation of the percentage of time group members are engaged in non-clinical activities. Capitation - Percentage of a practice's patients that are covered by capitation insurance programs. Physician executive - Practice has appointed a physician-member to manage the group. Management co. Practice has engaged the services of a MSO or PPMC.

${ }^{4}$ We also used indicator variables to compare intra-firm variation in compensation for firms with 5-7 members and those with 8-10 members to firms with more than 10 members. Consistent with the above result for size, neither indicator variable was significant.

${ }^{5}$ Control variables for metropolitan location and geographical region (suburban, rural, Northeast, etc.) are included in the model, but are not shown. Negelkerke R-square and chi-square statistic without metropolitan and regional controls are $20.9 \%$ and $95.56,21.3 \%$ and 43.23 , and $24.4 \%$ and 19.26 for models 1,2 and 3 , respectively.

$*, * *$, and $* * *$ indicate two-tailed significance levels of $10 \%, 5 \%$ and $1 \%$, respectively. 